Article

\title{
Bioactive Constituents from the Roots of Eurycoma longifolia
}

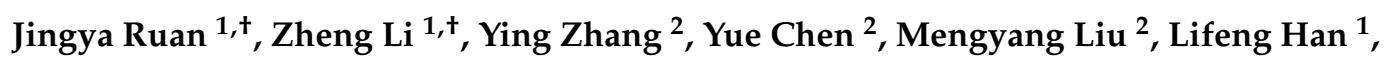 \\ Yi Zhang ${ }^{1,2, *}$ and Tao Wang ${ }^{1,2, *}$ \\ 1 Tianjin State Key Laboratory of Modern Chinese Medicine, 312 Anshanxi Road, Nankai District, \\ Tianjin 300193, China \\ 2 Tianjin Key Laboratory of TCM Chemistry and Analysis, Institute of Traditional Chinese Medicine, Tianjin \\ University of Traditional Chinese Medicine, 312 Anshanxi Road, Nankai District, Tianjin 300193, China \\ * Correspondence: zhwwxzh@tjutcm.edu.cn (Y.Z.); wangtao@tjutcm.edu.cn (T.W.); \\ Tel./Fax: +86-22-5959-6168 (T.W.) \\ + Theses authors contributed equally to this work.
}

Academic Editor: Maria da Graça Costa G. Miguel

Received: 12 August 2019; Accepted: 28 August 2019; Published: 30 August 2019

check for updates

\begin{abstract}
Four new phenolic components, eurylophenolosides A (1) and B (2), eurylolignanosides A (3) and B (4), along with twelve known compounds were isolated from the roots of Eurycoma longifolia Jack. The structure of these components was elucidated by using various spectral techniques and chemical reactions. Among the known isolates, syringaldehyde (12), 3-chloro-4-hydroxybenzoic acid (13), 3-chloro-4-hydroxyl benzoic acid-4-O- $\beta$-D-glucopyranoside (14), and isotachioside (15) were isolated from the Eurycoma genus for the first time. Further, the NMR data of $\mathbf{1 4}$ was reported here firstly. Meanwhile, the nitric oxide (NO) inhibitory activities of all compounds were examined in lipopolysaccharide (LPS)-stimulated RAW264.7 cells at $40 \mu \mathrm{M}$. As results, piscidinol A (6), 24-epi-piscidinol A (7), bourjotinolone A (10), and scopoletin (16) were found to play important role in suppressing NO levels without cytotoxicity. Furthermore, the Western blot method was used to investigate the mechanism of compounds $6,7, \mathbf{1 0}$, and $\mathbf{1 6}$ by analysing the level of inflammation related proteins, such as inducible nitric oxide synthase (iNOS), interleukin-6 (IL-6), and nuclear factor kappa-light-chain-enhancer of activated B cells (NF-kB) in LPS-stimulated RAW264.7 cells. Consequently, compounds 6, 7, 10, and 16 were found to significantly inhibit LPS-induced protein expression of IL-6, NF- $\mathrm{KB}$ and iNOS in NF- $\mathrm{KB}$ signaling pathway. Moreover, it was found that the protein expression inhibitory effects of 6,7 , and 16 exhibited in a dose-dependent manner. The mechanism may be related to the inhibition of the iNOS expressions through suppressing the IL-6-induced NF- KB pathway.
\end{abstract}

Keywords: Eurycoma longifolia roots; eurylophenolosides; eurylolignanosides; piscidinol A; 24-epipiscidinol A; bourjotinolone A; scopoletin; RAW 246.7 cell; anti-inflammatory activity

\section{Introduction}

As we know, inflammation is a very common and important pathological process. Although moderate inflammation is a benefit for the body, overreaction or a lack of it can cause some adverse reactions, and even lead to other deadly chronic disease such as cancer, Alzheimer's disease, diabetes, and atherosclerosis [1]. Thus, the discovery of anti-inflammatory drugs and the treatment of inflammation are particularly essential.

As a kind of immune cell distributed throughout the body, macrophages play a central role in the immune surveillance system [2]. Macrophages can immediately play an immune role indirectly by releasing various inflammatory agents after the pathogen enters the body. As one type of the 
macrophage-like cell line, the RAW 264.7 cell is a common cell line for studying microbiological immunology and other related research fields because of its strong ability to adhere to phagocytosis antigens [3].

Inflammatory response is closely related to inflammatory factors and inflammatory cells. Proinflammatory cytokines regulate the secretion of inflammatory factors. Cellular signalling pathways can regulate the transcription and synthesis of pro-inflammatory cytokines, which include Janus kinase-signal transduction and transcription activator (JAK-STAT), mitogen-activated protein kinase (MAPK), and nuclear factor kappa-light-chain-enhancer of activated B (NF- $\mathrm{kB}$ ) pathways. Among them, NF- $\mathrm{KB}$ is the main signaling pathway [4].

Lipopolysaccharides (LPS) can stimulate the acute inflammatory response of RAW 264.7 cells to release typical proinflammatory cytokines, such as tumor necrosis factor (TNF- $\alpha$ ) and interleukin 6 (IL-6) [1]. Then, protein kinase, NF- KB is activated. After this, the level of inducible nitric oxide synthase (iNOS) in an abnormal body is regulated to promote the synthesis of nitric oxide (NO), and then the expression of cyclooxygenase-2 (COX-2) is upregulated. The process will promote tissue damage and chronic disease.

Eurycoma longifolia Jack (Simaroubaceae family) is a wild shrub. As a commonly used medicine in Southeast Asian countries, it is mainly distributed in Malaysia, Vietnam, Thailand, and India. It is also known as one of the three national treasures of Malaysia, together with bird's nest and tin. Its roots and root bark possess multiple biological functions such as male testosterone level increasement, anti-fatigue, hypertension, fever treatment $[5,6]$, and so on. The main constituents in it are quassinoids, alkaloids, and terpenoids [7]. Pharmacological studies have shown that E. longifolia exhibited anti-malarial, anti-cancer, anti-inflammatory, and other effects [8-11]. Among them, anti-cancer and anti-malarial activities are research hotspots. However, the study of its anti-inflammatory activity is rare $[12,13]$.

In this paper, the phytochemistry and anti-inflammation therapeutic substance in E. longifolia roots were investigated. Chromatographies and spectral analysis techniques were combined to isolate and identify constituents from the plant. The inhibitory activities of all gained compounds against NO production in RAW 264.7 cells induced by LPS were evaluated. Furthermore, the anti-inflammatory mechanism of potential activity compounds was studied using the Western blot method.

\section{Results and Discussion}

The 70\% EtOH extract of E. longifolia roots was suspended in water and partitioned with EtOAc. The $\mathrm{H}_{2} \mathrm{O}$ soluble extract was subjected to D101 macroporous resin column chromatography (CC), and eluated with $\mathrm{H}_{2} \mathrm{O}$ and $95 \% \mathrm{EtOH}$, successively. Separation of the EtOAc fraction and $95 \% \mathrm{EtOH}$ eluated fraction by column chromatography (CC) such as silica gel, Sephadex LH-20, and preparative high-performance liquid chromatography (pHPLC) yielded four new phenolic components, namely eurylophenolosides A (1) and B (2), eurylolignanosides A (3) and B (4) (Figure 1). The structures of them were elucidated by using various spectral techniques $\left({ }^{1} \mathrm{H}\right.$ and ${ }^{13} \mathrm{C} N M R,{ }^{1} \mathrm{H}{ }^{1} \mathrm{H}$ COSY, HSQC, HMBC, UV, IR, MS, $\left.[\alpha]_{D}\right)$ and chemical reaction. Moreover, the twelve known isolates, hispidol B (5) [14,15], piscidinol A (6) [14], 24-epi-piscidinol A (7) [16], bourjotinolone B (8) [17], 3-episapeline A (9) [15], bourjotinolone A (10) [15], 3-methoxy-4-hydroxybenzoic acid (11) [18], syringaldehyde (12) [19,20], 3-chloro-4-hydroxybenzoic acid (13) [21], 3-chloro-4-hydroxyl benzoic acid-4-O- $\beta$-D-glucopyranoside (14), isotachioside (15) [22], and scopoletin (16) [23] (Figure 2) were identified by comparing the spectroscopic data with those reported in the corresponding literatures. Among the known compounds, 12-15 were isolated from the Eurycoma genus for the first time. And the NMR data of $\mathbf{1 4}$ was reported here firstly. 

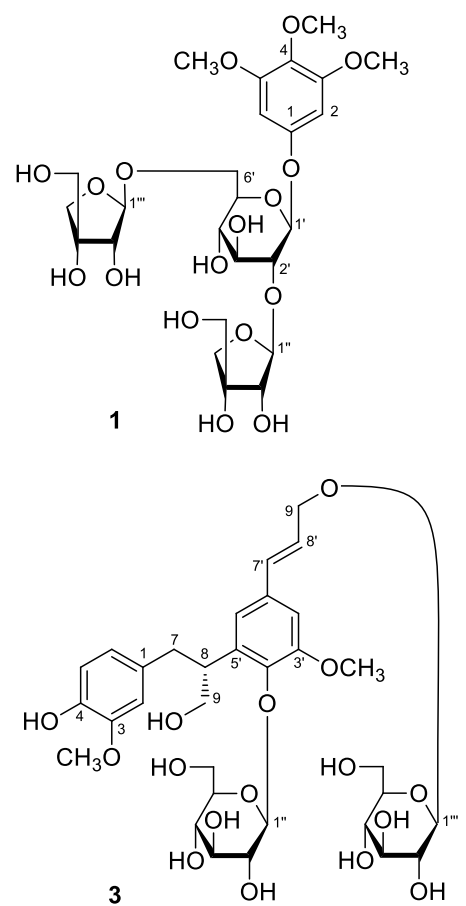
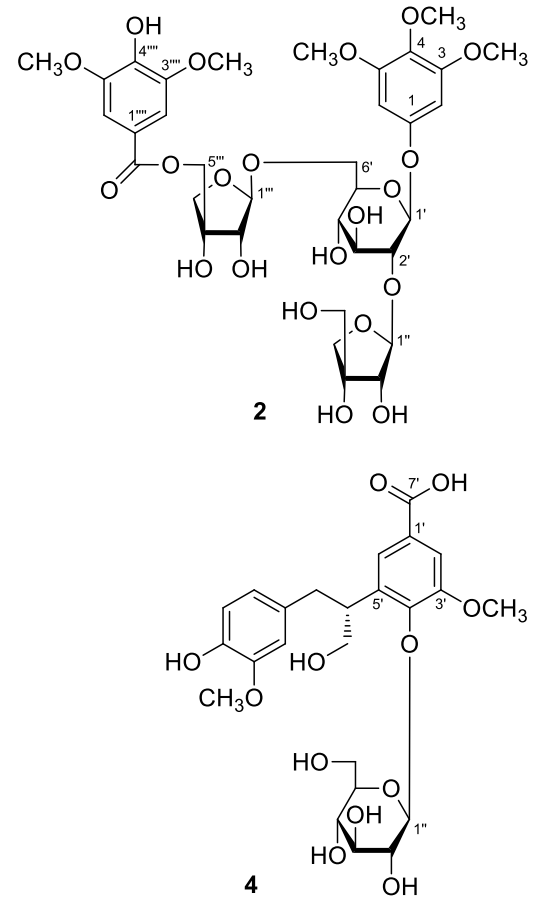

Figure 1. The new compounds 1-4 obtained from E. longifolia roots.<smiles>CC(C[C@H](O)[C@@H](O)C(C)(C)O)[C@]1(C)CCC2(C)C3=CC[C@H]4C(C)(C)[C@@H](O)CC[C@]4(C)C3CC[C@H]21</smiles>

5

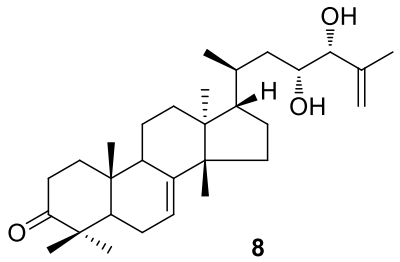<smiles>CC(C[C@@H](O)[C@@H](O)C(C)(C)O)[C@]1(C)CC[C@]2(C)C3=CC[C@H]4C(C)(C)C(=O)CC[C@]4(C)C3CC[C@@]12C</smiles>

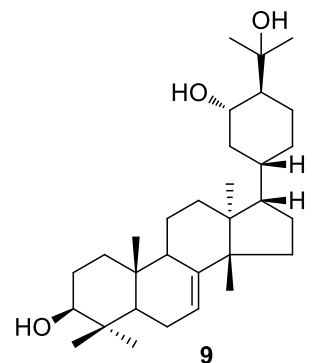<smiles>CC(C[C@@H](O)[C@@H](O)C(C)(C)O)[C@]1(C)CC[C@]2(C)C3=CC[C@H]4C(C)(C)C(=O)CC[C@]4(C)C3CC[C@H]21</smiles><smiles>CC(C)(O)[C@H]1CC[C@@H]([C@H]2CCC3(C)C4=CC[C@H]5C(C)(C)C(=O)CC[C@]5(C)C4CC[C@H]23)[C@H](O)C1</smiles><smiles>COc1cc(C(=O)O)ccc1O</smiles>

Figure 2. The known compounds 5-16 obtained from E. longifolia roots.

Eurylophenoloside A (1) was obtained as a white powder with negative optical rotation $\left([\alpha]_{\mathrm{D}}{ }^{25}\right.$ $-79.0, \mathrm{MeOH})$. Its molecular formula, $\mathrm{C}_{25} \mathrm{H}_{38} \mathrm{O}_{17}$, with seven degrees of unsaturation, was deduced from the quasimolecular ion peak at $m / z 633.2008[\mathrm{M}+\mathrm{Na}]^{+}$(calcd for $\mathrm{C}_{25} \mathrm{H}_{38} \mathrm{O}_{17} \mathrm{Na}$, 633.2001) in the HRESI-TOF-MS. Infrared (IR) spectrum of it showed characteristic absorptions of hydroxyl $\left(3374 \mathrm{~cm}^{-1}\right)$, aromatic ring $\left(1601,1505,1462 \mathrm{~cm}^{-1}\right)$, and glycosyl bond $\left(1067 \mathrm{~cm}^{-1}\right)$. Its ${ }^{1} \mathrm{H}$ and ${ }^{13} \mathrm{C}$ NMR spectra (Table 1 ) showed signals attributed to one symmetrical 1,3,4,5-tetra-substituted phenyl [ $\delta 6.94(2 \mathrm{H}, \mathrm{s}$, $\mathrm{H}-2,6)]$, three methoxyls $\left[\delta 3.79\left(3 \mathrm{H}, \mathrm{s}, 4-\mathrm{OCH}_{3}\right), 3.88\left(6 \mathrm{H}, \mathrm{s}, 3,5-\mathrm{OCH}_{3}\right)\right]$. The long-range correlation 
observations from $\delta_{\mathrm{H}} 6.94(\mathrm{H}-2,6)$ to $\delta_{\mathrm{C}} 134.3(\mathrm{C}-4), 154.4(\mathrm{C}-3,5), 155.5(\mathrm{C}-1) ; \delta_{\mathrm{H}} 3.88\left(3,5-\mathrm{OCH}_{3}\right)$ to $\delta_{\mathrm{C}}$ $154.4(\mathrm{C}-3,5) ; \delta_{\mathrm{H}} 3.79\left(4-\mathrm{OCH}_{3}\right)$ to $\delta_{\mathrm{C}} 134.3(\mathrm{C}-4)$ showed in $\mathrm{HMBC}$ spectrum (Figure 3$)$ suggested the aglycon of 1 was 3,4,5-trimethoxyphenol. A total of 25 signals were displayed in its ${ }^{13} \mathrm{C}$ NMR spectrum, except for the nine ones belonging to 3,4,5-trimethoxyphenol moiety, there were another sixteen carbon signals. Combining with three signals of anomeric protons $\left[\delta 5.38\left(1 \mathrm{H}, \mathrm{d}, J=7.8 \mathrm{~Hz}, \mathrm{H}-1^{\prime}\right), 5.66(1 \mathrm{H}\right.$, $\left.\left.\mathrm{d}, J=2.4 \mathrm{~Hz}, \mathrm{H}-1^{\prime \prime \prime}\right), 6.60\left(1 \mathrm{H}, \mathrm{br} . \mathrm{s}, \mathrm{H}-\mathrm{1}^{\prime \prime}\right)\right]$ displayed in its ${ }^{1} \mathrm{H}$ NMR spectrum, the existences of one hexose and two pentoses were speculated. D-glucose was obtained when compound $\mathbf{1}$ was hydrolysed with $1 \mathrm{M} \mathrm{HCl}$, which was identified by retention time and optical rotation using chiral detection by HPLC analysis [24]. Furtherly, it was clarified to be $\beta$-D-glucopyranosyl since the coupling constant of anomeric proton was $7.8 \mathrm{~Hz}$. The correlation from $\delta_{\mathrm{H}} 5.38\left(\mathrm{H}-1^{\prime}\right)$ to $\delta_{\mathrm{C}} 155.5(\mathrm{C}-1)$ suggested the $\beta$-D-glucopyranosyl linked with $\mathrm{C}-1$ position of aglycon. Moreover, the long-range correlations from $\delta_{\mathrm{H}} 4.50\left(\mathrm{H}-2^{\prime}\right)$ to $\delta_{\mathrm{C}} 110.5\left(\mathrm{C}-1^{\prime \prime}\right) ; \delta_{\mathrm{H}} 5.66\left(\mathrm{H}-1^{\prime \prime \prime}\right)$ to $\delta_{\mathrm{C}} 69.0\left(\mathrm{C}-6^{\prime}\right)$ indicated both 1- and 6-positions of $\beta$-D-glucopyranosyl were substituted by pentose group. The chemical shifts of $\mathrm{H}-2$ of two pentoses were assigned according to the proton and proton correlations between $\delta_{\mathrm{H}} 6.60\left(\mathrm{H}-1^{\prime \prime}\right)$ and $\delta_{\mathrm{H}} 4.77$ $\left(\mathrm{H}-2^{\prime \prime}\right) ; \delta_{\mathrm{H}} 5.66\left(\mathrm{H}-1^{\prime \prime \prime}\right)$ and $\delta_{\mathrm{H}} 4.69$ (H-2"'). Furthermore, the linkage positions of them were elucidated by the correlations fom $\delta_{\mathrm{H}} 6.60\left(\mathrm{H}-1^{\prime \prime}\right)$ to $\delta_{\mathrm{C}} 81.0\left(\mathrm{C}-3^{\prime \prime}\right) ; \delta_{\mathrm{H}} 4.25,4.28\left(\mathrm{H}_{2}-5^{\prime \prime}\right)$ to $\delta_{\mathrm{C}} 75.9\left(\mathrm{C}-4^{\prime \prime}\right), 81.0\left(\mathrm{C}-3^{\prime \prime}\right)$; $\delta_{\mathrm{H}} 5.66\left(\mathrm{H}-1^{\prime \prime \prime}\right)$ to $\delta_{\mathrm{C}} 80.3\left(\mathrm{C}-3^{\prime \prime \prime}\right) ; \delta_{\mathrm{H}} 4.09,4.14\left(\mathrm{H}_{2}-5^{\prime \prime \prime}\right)$ to $\delta_{\mathrm{C}} 74.9\left(\mathrm{C}-4^{\prime \prime \prime}\right), 80.3$ (C-3"') observed in its $\mathrm{HMBC}$ spectrum. Finally, both of the two pentoses were identified as $\beta$-D-apiofuranosyl by using the method as following. According to the coupling constants of anomeric protons $\left({ }^{3} J_{1,2}<4 \mathrm{~Hz}\right)$ and the trends in ${ }^{13} \mathrm{C}$ NMR data of two pentoses, we could speculate them were $\beta$-D- or $\alpha$-D-apiofuranosyl [25]. Finally, both of them were clarified to be $\beta$-D-apiofuranosyl by the NOESY experiment. The NOE correlations were observed between $\delta_{\mathrm{H}} 4.77\left(\mathrm{H}-2^{\prime \prime}\right)$ and $\delta_{\mathrm{H}} 4.25,4.28\left(\mathrm{H}_{2}-5^{\prime \prime}\right) ; \delta_{\mathrm{H}} 4.69\left(\mathrm{H}-2^{\prime \prime \prime}\right)$ and $\delta_{\mathrm{H}}$ $4.09,4.14\left(\mathrm{H}_{2}-5^{\prime \prime \prime}\right)$ in the NOESY spectrum. Therefore, the structure of 1 was determined, which was named eurylophenoloside A.

Table 1. ${ }^{1} \mathrm{H}$ and ${ }^{13} \mathrm{C}$ NMR data of $\mathbf{1}$ in $\mathrm{C}_{5} \mathrm{D}_{5} \mathrm{~N}$.

\begin{tabular}{|c|c|c|c|c|c|}
\hline No. & $\delta_{C}$ & $\delta_{H}(J$ in $\mathrm{Hz})$ & No. & $\delta_{C}$ & $\delta_{H}(J$ in $\mathrm{Hz})$ \\
\hline 1 & 155.5 & - & $4^{\prime \prime}$ & 75.9 & $4.47(\mathrm{~d}, 9.6)$ \\
\hline 2,6 & 95.9 & $6.94(\mathrm{~s})$ & & & $4.93(\mathrm{~d}, 9.6)$ \\
\hline 3,5 & 154.4 & - & $5^{\prime \prime}$ & 66.6 & $4.25(\mathrm{~d}, 11.4)$ \\
\hline 4 & 134.3 & - & & & $4.28(\mathrm{~d}, 11.4)$ \\
\hline $1^{\prime}$ & 101.9 & $5.38(\mathrm{~d}, 7.8)$ & $1^{\prime \prime \prime}$ & 111.0 & $5.66(\mathrm{~d}, 2.4)$ \\
\hline $2^{\prime}$ & 77.1 & $4.50(\mathrm{dd}, 8.4,7.8)$ & $2^{\prime \prime \prime}$ & 77.6 & $4.69(\mathrm{~d}, 2.4)$ \\
\hline $3^{\prime}$ & 79.0 & $4.31(\mathrm{dd}, 9.0,8.4)$ & $3^{\prime \prime \prime}$ & 80.3 & - \\
\hline $4^{\prime}$ & 71.8 & $3.95(\mathrm{dd}, 9.0,9.0)$ & $4^{\prime \prime \prime}$ & 74.9 & $4.31(\mathrm{~d}, 9.6)$ \\
\hline $5^{\prime}$ & 77.2 & $4.18(\mathrm{~m})$ & & & $4.55(\mathrm{~d}, 9.6)$ \\
\hline \multirow[t]{2}{*}{$6^{\prime}$} & 69.0 & $4.03(\mathrm{dd}, 10.8,7.2)$ & $5^{\prime \prime \prime}$ & 65.2 & $4.09(\mathrm{~d}, 11.4)$ \\
\hline & & 4.78 (br. d, ca. 11) & & & $4.14(\mathrm{~d}, 11.4)$ \\
\hline $1^{\prime \prime}$ & 110.5 & 6.60 (br. s) & $3,5-\mathrm{OCH}_{3}$ & 56.2 & $3.88(\mathrm{~s})$ \\
\hline $2^{\prime \prime}$ & 78.0 & 4.77 (br. s) & $4-\mathrm{OCH}_{3}$ & 60.6 & $3.79(\mathrm{~s})$ \\
\hline $3^{\prime \prime}$ & 81.0 & - & & & \\
\hline
\end{tabular}



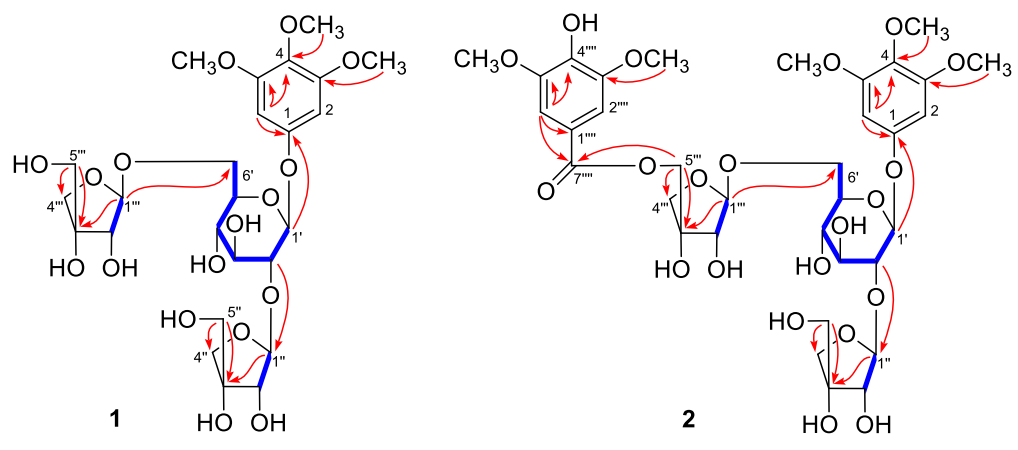

${ }^{1} \mathrm{H}^{1} \mathrm{H} \cos Y:-\mathrm{HMBC}: \frown$

Figure 3. The main ${ }^{1} \mathrm{H}^{1} \mathrm{H}$ COSY and HMBC correlations of $\mathbf{1}$ and 2.

Eurylophenoloside B (2) was isolated as a white powder, too. Its molecular formula, $\mathrm{C}_{34} \mathrm{H}_{46} \mathrm{O}_{21}$, was established by positive-ion HRESI-TOF-MS [ $\mathrm{m} / \mathrm{z} 813.2438[\mathrm{M}+\mathrm{H}]^{+}$(calcd for $\mathrm{C}_{34} \mathrm{H}_{47} \mathrm{O}_{21}, 813.2424$ )]. The IR spectrum of it not only presented the characteristic absorptions of hydroxyl $\left(3357 \mathrm{~cm}^{-1}\right)$, aromatic ring $\left(1603,1506,1462 \mathrm{~cm}^{-1}\right)$, glycosyl bond $\left(1067 \mathrm{~cm}^{-1}\right)$, but also the characteristic absorption of unsaturated carboxyl $\left(1704 \mathrm{~cm}^{-1}\right)$. Comparing its ${ }^{1} \mathrm{H}$ and ${ }^{13} \mathrm{C}$ NMR spectra (Table 2) with those of 1 , we found that the chemical shift value of C-6"' was increased by 2.9, but that of C-5"' was reduced by 1.4 in 2 . Then, C-6"' was supposed to be replaced by an acyl group. Moreover, there were two more symmetrical methoxyl $\left[\delta 3.77\left(6 \mathrm{H}, \mathrm{s}, 3\right.\right.$ 3"', $\left.\left.5^{\prime \prime \prime \prime}-\mathrm{OCH}_{3}\right)\right]$, two more symmetrical aromatic proton $\left[\delta 7.68\left(2 \mathrm{H}, \mathrm{s}, \mathrm{H}-2^{\prime \prime \prime \prime}, 6^{\prime \prime \prime \prime}\right)\right]$, as well as one more carbonyl [ $\left.\delta_{\mathrm{C}} 166.7\left(\mathrm{C}-7^{\prime \prime \prime \prime}\right)\right]$ signals displayed in the NMR spectra of 2 than $\mathbf{1}$. The presence of them were clarified by the long-range correlations from $\delta_{\mathrm{H}} 7.68\left(\mathrm{H}-2^{\prime \prime \prime \prime}, 6^{\prime \prime \prime \prime}\right)$ to $\delta_{\mathrm{C}} 120.1\left(\mathrm{C}-1^{\prime \prime \prime \prime}\right), 143.0\left(\mathrm{C}-4^{\prime \prime \prime \prime}\right), 148.7\left(\mathrm{C}-3^{\prime \prime \prime}, 5^{\prime \prime \prime}\right), 166.7\left(\mathrm{C}-7^{\prime \prime \prime \prime}\right) ; \delta_{\mathrm{H}} 3.77$ $\left(3^{\prime \prime \prime \prime}, 5^{\prime \prime \prime \prime}-\mathrm{OCH}_{3}\right)$ to $\delta_{\mathrm{C}} 148.7\left(\mathrm{C}-3^{\prime \prime \prime \prime}, 5^{\prime \prime \prime}\right)$ observed in its HMBC spectrum, and the moiety was decuced to be 3,5-dimethoxy-4-hydroxybenzoyl. Finally, the correlation from $\delta_{\mathrm{H}} 4.86,4.90\left(\mathrm{H}_{2}-5^{\prime \prime \prime}\right)$ to $\delta_{\mathrm{C}}$ 166.7 (C-7"'") indicated that 3,5-dimethoxy-4-hydroxybenzoyl connected with C-5"' of compound 1, and eurylophenoloside B (2) was formed.

Table 2. ${ }^{1} \mathrm{H}$ and ${ }^{13} \mathrm{C}$ NMR data of 2 in $\mathrm{C}_{5} \mathrm{D}_{5} \mathrm{~N}$.

\begin{tabular}{|c|c|c|c|c|c|}
\hline No. & $\delta_{C}$ & $\delta_{\mathrm{H}}(J$ in $\mathrm{Hz})$ & No. & $\delta_{C}$ & $\delta_{H}(J$ in $\mathbf{H z})$ \\
\hline 1 & 155.4 & - & $1^{\prime \prime \prime}$ & 110.6 & $5.69(\mathrm{~d}, 3.0)$ \\
\hline 2,6 & 96.0 & $6.92(\mathrm{~s})$ & $2^{\prime \prime \prime}$ & 78.6 & $4.62(\mathrm{~d}, 3.0)$ \\
\hline 3,5 & 154.3 & - & $3^{\prime \prime \prime}$ & 78.7 & - \\
\hline 4 & 134.1 & - & $4^{\prime \prime \prime}$ & 74.8 & $4.39(\mathrm{~d}, 9.5)$ \\
\hline $1^{\prime}$ & 101.9 & $5.40(\mathrm{~d}, 8.0)$ & & & $4.49(\mathrm{~d}, 9.5)$ \\
\hline $2^{\prime}$ & 77.2 & $4.49(\mathrm{dd}, 9.0,8.0)$ & $5^{\prime \prime \prime}$ & 67.8 & $4.86(\mathrm{~d}, 11.5)$ \\
\hline $3^{\prime}$ & 78.9 & $4.32(\mathrm{dd}, 9.0,9.0)$ & & & $4.90(\mathrm{~d}, 11.5)$ \\
\hline $4^{\prime}$ & 71.7 & $3.98(\mathrm{dd}, 9.5,9.0)$ & $1^{\prime \prime \prime \prime}$ & 120.1 & - \\
\hline $5^{\prime}$ & 77.1 & $4.17(\mathrm{~m})$ & $2^{\prime \prime \prime \prime}$ & 108.3 & $7.68(\mathrm{~s})$ \\
\hline \multirow[t]{2}{*}{$6^{\prime}$} & 68.9 & $4.06(\mathrm{dd}, 11.5,7.5)$ & $3^{\prime \prime \prime \prime}$ & 148.7 & - \\
\hline & & 4.76 (br. d, ca. 12) & $4^{\prime \prime \prime \prime}$ & 143.0 & - \\
\hline $1^{\prime \prime}$ & 110.5 & 6.57 (br. s) & $5^{\prime \prime \prime \prime}$ & 148.7 & - \\
\hline $2^{\prime \prime}$ & 78.1 & 4.78 (br. s) & $6^{\prime \prime \prime \prime}$ & 108.3 & $7.68(\mathrm{~s})$ \\
\hline $3^{\prime \prime}$ & 81.0 & - & $7^{\prime \prime \prime \prime}$ & 166.7 & - \\
\hline \multirow[t]{2}{*}{$4^{\prime \prime}$} & 75.8 & $4.46(\mathrm{~d}, 9.5)$ & $3,5-\mathrm{OCH}_{3}$ & 56.2 & $3.87(\mathrm{~s})$ \\
\hline & & $4.91(\mathrm{~d}, 9.5)$ & $4-\mathrm{OCH}_{3}$ & 60.6 & $3.79(\mathrm{~s})$ \\
\hline \multirow[t]{2}{*}{$5^{\prime \prime}$} & 66.5 & $4.24(\mathrm{~d}, 11.0)$ & $3^{\prime \prime \prime \prime}, 5^{\prime \prime \prime \prime}-\mathrm{OCH}_{3}$ & 56.3 & $3.77(\mathrm{~s})$ \\
\hline & & $4.27(\mathrm{~d}, 11.0)$ & & & \\
\hline
\end{tabular}

Eurylolignanoside A (3) was obtained as a white powder with negative optical rotation $\left([\alpha]_{\mathrm{D}}{ }^{25}\right.$ $-47.2, \mathrm{MeOH})$. HRESI-TOF-MS determination result $\left[\mathrm{m} / \mathrm{z} 707.2521[\mathrm{M}+\mathrm{Na}]^{+}\left(\right.\right.$calcd for $\mathrm{C}_{32} \mathrm{H}_{44} \mathrm{O}_{16} \mathrm{Na}$, 707.2522)] revealed its molecular formula was $\mathrm{C}_{32} \mathrm{H}_{44} \mathrm{O}_{16}$. D-glucose was analyzed from its acid 
hydrolysis product [24]. Its ${ }^{1} \mathrm{H}$ and ${ }^{13} \mathrm{C}$ NMR spectra (Table 3) indicated the existence of one $\mathrm{ABX}$ spin coupling systematic phenyl [ $6.48(1 \mathrm{H}, \mathrm{dd}, J=1.5,8.0 \mathrm{~Hz}, \mathrm{H}-6), 6.56(1 \mathrm{H}, \mathrm{d}, J=8.0 \mathrm{~Hz}, \mathrm{H}-5)$, $6.57(1 \mathrm{H}, \mathrm{d}, J=1.5 \mathrm{~Hz}, \mathrm{H}-2)]$, one 1,3,4,5-tetrasubstituted phenyl [ $66.95\left(1 \mathrm{H}, \mathrm{d}, J=2.0, \mathrm{H}-2^{\prime}\right), 6.92(1 \mathrm{H}$, d, $\left.J=2.0 \mathrm{~Hz}, \mathrm{H}-6^{\prime}\right)$ ], two $\beta$-D-glucopyranosyls [ $\delta 4.37\left(1 \mathrm{H}, \mathrm{d}, J=8.0 \mathrm{~Hz}, \mathrm{H}-1^{\prime \prime \prime}\right), 4.68(1 \mathrm{H}, \mathrm{d}, J=7.5 \mathrm{~Hz}$, $\left.\left.\mathrm{H}-1^{\prime \prime}\right)\right]$, along with two methoxyls [ $\left.83.69\left(3 \mathrm{H}, \mathrm{s}, 3-\mathrm{OCH}_{3}\right), 3.83\left(3 \mathrm{H}, \mathrm{s}, 3^{\prime}-\mathrm{OCH}_{3}\right)\right]$. In addition to the 26 signals represented by the above mentioned moieties and functional groups, there were six more carbon signals displaying in its ${ }^{13} \mathrm{C}$ NMR spectrum, which suggested compound 3 was one of phenylpropane glycoside. The correlations between $\delta_{\mathrm{H}} 3.97(\mathrm{H}-8)$ and $\delta_{\mathrm{H}} 2.73,2.96\left(\mathrm{H}_{2}-7\right), 3.69,3.76$ $\left(\mathrm{H}_{2}-9\right)$ showed in the ${ }^{1} \mathrm{H}^{1} \mathrm{H}$ COSY spectrum suggested the presence of " $-\mathrm{CH}_{2}-\mathrm{CH}-\mathrm{CH}_{2} \mathrm{O}-$ " moiety. Moreover, the exitence of "- $\mathrm{CH}=\mathrm{CH}-\mathrm{CH}_{2} \mathrm{OH}$ " moiety was clarified by the correlations between $\delta_{\mathrm{H}}$ $6.30\left(\mathrm{H}-8^{\prime}\right)$ and $\delta_{\mathrm{H}} 4.33,4.52\left(\mathrm{H}_{2}-9^{\prime}\right), 6.65\left(\mathrm{H}-7^{\prime}\right)$. On the other hand, the coupling constant $(J=16.0 \mathrm{~Hz})$ between $\mathrm{H}-\mathrm{7}^{\prime}$ and $\mathrm{H}-\mathrm{8}^{\prime}$ indicated that the two protons presented trans configuration. The planar structure was clarified by the long-range correlations observed from the followling proton to carbon pairs: $\delta_{\mathrm{H}} 3.69\left(3-\mathrm{OCH}_{3}\right), 6.56(\mathrm{H}-5)$ to $\delta_{\mathrm{C}} 148.4(\mathrm{C}-3) ; \delta_{\mathrm{H}} 6.48(\mathrm{H}-6), 6.57(\mathrm{H}-2)$ to $\delta_{\mathrm{C}} 145.4(\mathrm{C}-4) ; \delta_{\mathrm{H}}$ 2.73, $2.96\left(\mathrm{H}_{2}-7\right)$ to $\delta_{\mathrm{C}} 113.8(\mathrm{C}-2), 122.6(\mathrm{C}-6), 133.2(\mathrm{C}-1), 139.0\left(\mathrm{C}-5^{\prime}\right) ; \delta_{\mathrm{H}} 3.97(\mathrm{H}-8)$ to $\delta_{\mathrm{C}} 119.4\left(\mathrm{C}-6^{\prime}\right)$, $133.2(\mathrm{C}-1), 139.0\left(\mathrm{C}-5^{\prime}\right), 145.2\left(\mathrm{C}-4^{\prime}\right) ; \delta_{\mathrm{H}} 6.92\left(\mathrm{H}-6^{\prime}\right), 6.95\left(\mathrm{H}-2^{\prime}\right)$ to $\delta_{\mathrm{C}} 145.2\left(\mathrm{C}-4^{\prime}\right) ; \delta_{\mathrm{H}} 3.83\left(3^{\prime}-\mathrm{OCH}_{3}\right)$, $6.95\left(\mathrm{H}-2^{\prime}\right)$ to $\delta_{\mathrm{C}} 153.5\left(\mathrm{C}-3^{\prime}\right) ; \delta_{\mathrm{H}} 6.65\left(\mathrm{H}-7^{\prime}\right)$ to $\delta_{\mathrm{C}} 109.2\left(\mathrm{C}-2^{\prime}\right), 119.4\left(\mathrm{C}-6^{\prime}\right), 135.2\left(\mathrm{C}-1^{\prime}\right) ; \delta_{\mathrm{H}} 4.68\left(\mathrm{H}-1^{\prime \prime}\right)$ to $\delta_{\mathrm{C}} 145.2\left(\mathrm{C}-4^{\prime}\right) ; \delta_{\mathrm{H}} 4.37\left(\mathrm{H}-1^{\prime \prime \prime}\right)$ to $\delta_{\mathrm{C}} 70.8\left(\mathrm{C}-9^{\prime}\right)$ (Figure 4$)$. The chemical shift value of $\mathrm{C}-8\left(\delta_{\mathrm{C}} 42.9\right.$, in $\mathrm{CD}_{3} \mathrm{OD}$ ) suggested the absolute configuration of it might be $8 R$ [26]. Finally, it was clarified by its cotton effect [mdeg -23.1 (259 nm)] displayed in circular dichroism (CD) spectrum [27]. Thus, the structure of eurylolignanoside A (3) was elucidated.

Table 3. ${ }^{1} \mathrm{H}$ and ${ }^{13} \mathrm{C}$ NMR data of 3 in $\mathrm{CD}_{3} \mathrm{OD}$.

\begin{tabular}{|c|c|c|c|c|c|}
\hline No. & $\delta_{C}$ & $\delta_{H}(J$ in $\mathrm{Hz})$ & No. & $\delta_{C}$ & $\delta_{\mathrm{H}}(J$ in $\mathrm{Hz})$ \\
\hline 1 & 133.2 & - & $9^{\prime}$ & 70.8 & $4.33(\mathrm{ddd}, 13.0,6.0,1.0)$ \\
\hline 2 & 113.8 & $6.57(\mathrm{~d}, 1.5)$ & & & $4.52(\mathrm{ddd}, 13.0,6.0,1.0)$ \\
\hline 3 & 148.4 & - & $1^{\prime \prime}$ & 105.4 & $4.68(\mathrm{~d}, 7.5)$ \\
\hline 4 & 145.4 & - & $2^{\prime \prime}$ & 76.0 & $3.46(\mathrm{dd}, 8.0,7.5)$ \\
\hline 5 & 115.7 & $6.56(\mathrm{~d}, 8.0)$ & $3^{\prime \prime}$ & 78.0 & $3.41(\mathrm{dd}, 8.0,8.0)$ \\
\hline 6 & 122.6 & $6.48(\mathrm{dd}, 8.0,1.5)$ & $4^{\prime \prime}$ & 71.3 & $3.37(\mathrm{dd}, 8.5,8.5)$ \\
\hline \multirow[t]{2}{*}{7} & 39.2 & $2.73(\mathrm{dd}, 14.0,9.5)$ & $5^{\prime \prime}$ & 77.9 & $3.12(\mathrm{~m})$ \\
\hline & & $2.96(\mathrm{dd}, 14.0,5.5)$ & $6^{\prime \prime}$ & 62.5 & $3.66(\mathrm{~m}$, overlapped $)$ \\
\hline 8 & 42.8 & $3.97(\mathrm{~m})$ & & & 3.77 (m, overlapped) \\
\hline \multirow[t]{2}{*}{9} & 66.8 & $3.69(\mathrm{~m}$, overlapped $)$ & $1^{\prime \prime \prime}$ & 103.3 & $4.37(\mathrm{~d}, 8.0)$ \\
\hline & & $3.76(\mathrm{~m}$, overlapped $)$ & $2^{\prime \prime \prime}$ & 75.2 & $3.24(\mathrm{dd}, 8.5,8.0)$ \\
\hline $1^{\prime}$ & 135.2 & - & $3^{\prime \prime \prime}$ & 78.2 & $3.37(\mathrm{dd}, 8.5,8.5)$ \\
\hline $2^{\prime}$ & 109.2 & $6.95(\mathrm{~d}, 2.0)$ & $4^{\prime \prime \prime}$ & 71.7 & $3.29(\mathrm{~m}$, overlapped $)$ \\
\hline $3^{\prime}$ & 153.5 & - & $5^{\prime \prime \prime}$ & 78.1 & $3.29(\mathrm{~m}$, overlapped $)$ \\
\hline $4^{\prime}$ & 145.2 & - & $6^{\prime \prime \prime}$ & 62.9 & $3.68(\mathrm{~m}$, overlapped $)$ \\
\hline $5^{\prime}$ & 139.0 & - & & & $3.88(\mathrm{dd}, 12.0,2.0)$ \\
\hline $6^{\prime}$ & 119.4 & $6.92(\mathrm{~d}, 2.0)$ & $3-\mathrm{OCH}_{3}$ & 56.3 & $3.69(\mathrm{~s})$ \\
\hline $7^{\prime}$ & 133.7 & 6.65 (br. d, ca. 16.0) & $3^{\prime}-\mathrm{OCH}_{3}$ & 56.4 & $3.83(\mathrm{~s})$ \\
\hline $8^{\prime}$ & 126.4 & $6.30(\mathrm{dt}, 16.0,6.0)$ & & & \\
\hline
\end{tabular}



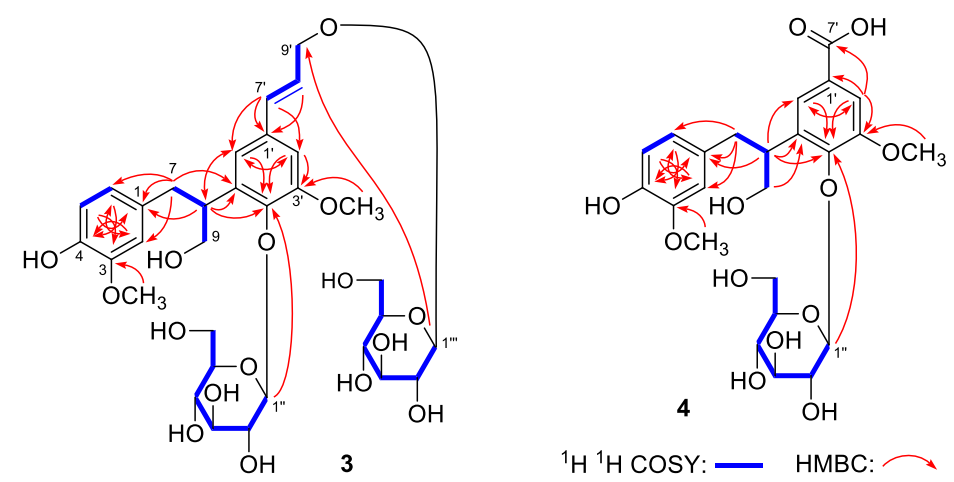

Figure 4. The main ${ }^{1} \mathrm{H}^{1} \mathrm{H}$ COSY and HMBC correlations of 3 and 4.

Eurylolignanoside B (4) was a negative optical active $\left([\alpha]_{\mathrm{D}}^{25}-42.5, \mathrm{MeOH}\right)$ white powder. Its molecular formula, $\mathrm{C}_{24} \mathrm{H}_{30} \mathrm{O}_{12}\left(\mathrm{~m} / z 509.1666[\mathrm{M}-\mathrm{H}]^{-}\right.$; calcd for $\left.\mathrm{C}_{24} \mathrm{H}_{29} \mathrm{O}_{12}, 509.1666\right)$ was deduced by HRESI-TOF-MS analysis. The ${ }^{1} \mathrm{H}$ and ${ }^{13} \mathrm{C}$ NMR (Table 4) as well as various $2 \mathrm{D}$ NMR spectra $\left({ }^{1} \mathrm{H}^{1} \mathrm{H}\right.$ COSY, HSQC, HMBC) suggested its structure was very similar to that of 3 , except that the signals due to one trans-hydroxypropenyl and one $\beta$-D-glucopyranosyl disappeared, while the signals belonging to one carboxyl [ $\left.\delta_{\mathrm{C}} 170.4\left(\mathrm{C}-7^{\prime}\right)\right]$ appeared. The substitute position of carboxyl was clarified by the long-range correlations from $\delta_{\mathrm{H}} 7.49\left(\mathrm{H}-2^{\prime}\right)$ to $\delta_{\mathrm{C}} 122.6\left(\mathrm{C}-6^{\prime}\right), 148.8\left(\mathrm{C}-4^{\prime}\right), 153.2\left(\mathrm{C}-3^{\prime}\right), 170.4\left(\mathrm{C}-7^{\prime}\right)$ (Figure 4). Moreover, the existence of D-glucose was elucidated by the $\mathrm{HCl}$ hydrolysis result [24]. The absolute configuration of C-8 was determined as $R$ by using the same method $[26,27]$ as those for compound 3, and the structure of 4 was elucidated and named as eurylolignanoside B.

Table 4. ${ }^{1} \mathrm{H}$ and ${ }^{13} \mathrm{C}$ NMR data of 4 in $\mathrm{CD}_{3} \mathrm{OD}$.

\begin{tabular}{|c|c|c|c|c|c|}
\hline No. & $\delta_{C}$ & $\delta_{H}(J$ in $\mathbf{H z})$ & No. & $\delta_{C}$ & $\delta_{H}(J$ in $\mathrm{Hz})$ \\
\hline 1 & 133.1 & - & $4^{\prime}$ & 148.8 & - \\
\hline 2 & 113.8 & $6.60(\mathrm{~d}, 1.5)$ & $5^{\prime}$ & 139.0 & - \\
\hline 3 & 148.5 & - & $6^{\prime}$ & 122.6 & 7.63 (br. s) \\
\hline 4 & 145.4 & - & $7^{\prime}$ & 170.4 & - \\
\hline 5 & 115.8 & $6.57(\mathrm{~d}, 8.0)$ & $1^{\prime \prime}$ & 105.0 & $4.80(\mathrm{~d}, 8.0)$ \\
\hline 6 & 122.6 & $6.49(\mathrm{dd}, 8.0,1.5)$ & $2^{\prime \prime}$ & 76.0 & $3.48(\mathrm{dd}, 8.0,8.0)$ \\
\hline \multirow[t]{2}{*}{7} & 39.3 & $2.73(\mathrm{dd}, 14.0,9.5)$ & $3^{\prime \prime}$ & 77.9 & $3.43(\mathrm{dd}, 9.0,8.0)$ \\
\hline & & $2.99(\mathrm{dd}, 14.0,6.0)$ & $4^{\prime \prime}$ & 71.2 & $3.39(\mathrm{dd}, 8.5,8.5)$ \\
\hline 8 & 43.0 & $3.99(\mathrm{~m})$ & $5^{\prime \prime}$ & 78.1 & $3.13(\mathrm{~m})$ \\
\hline \multirow[t]{2}{*}{9} & 66.7 & $3.71(\mathrm{~m})$ & $6^{\prime \prime}$ & 62.4 & $3.66(\mathrm{dd}, 12.0,5.0)$ \\
\hline & & $3.79(\mathrm{~m})$ & & & $3.75(\mathrm{dd}, 12.0,2.0)$ \\
\hline $1^{\prime}$ & 148.5 & - & $3-\mathrm{OCH}_{3}$ & 56.3 & $3.71(\mathrm{~s})$ \\
\hline $2^{\prime}$ & 112.5 & 7.49 (br. s) & $3^{\prime}-\mathrm{OCH}_{3}$ & 56.4 & 3.85 (s) \\
\hline $3^{\prime}$ & 153.2 & - & & & \\
\hline
\end{tabular}

By comparing the spectroscopic data with those reported in literature, the known compounds 5-16 were identified.

$\mathrm{NO}$ is a signaling factor implicated in a variety of inflammatory conditions. Agents that block NO production might be beneficial for the treatment of inflammatory responses. In order to clarify the anti-inflammatory effects of 1-16, the effects of compounds 1-16 on LPS-stimulated NO release were measured through the Griess reaction in RAW264.7 cells [28].

Before the experiment, a dimethyl thiazolyl diphenyl tetrazolium (MTT) assay was used to test the cytotoxicities of 1-16. It was found that all of them displayed no significant cytotoxicity at $40 \mu \mathrm{M}$ concentration (Figure S29). Then, under this concentration, in vitro potential anti-inflammatory effects of all isolates were investigated. As a result, compound 6 exhibited singnificant inhibitoty effects of the NO release, and compounds 7, 10 and $\mathbf{1 6}$ showed moderate inhibitoty activities of the NO production (Table 5). 
Table 5. Inhibitory effects of compounds 1-16 on NO production in RAW 264.7 cells.

\begin{tabular}{cccc}
\hline NO. & NRC (\%) & NO. & NRC (\%) \\
\hline Normal & $2.2 \pm 0.4$ & 8 & $101.3 \pm 6.1$ \\
Control & $100 \pm 3.5$ & 9 & $90.3 \pm 5.3^{*}$ \\
DEX & $82.7 \pm 3.1^{* * *}$ & 10 & $69.0 \pm 2.7^{* * *}$ \\
1 & $93.6 \pm 3.7^{*}$ & 11 & $98.5 \pm 2.8$ \\
2 & $101.1 \pm 3.6$ & 12 & $96.3 \pm 2.4$ \\
3 & $102.2 \pm 4.0$ & 13 & $95.1 \pm 0.9$ \\
4 & $96.0 \pm 1.1$ & 14 & $98.2 \pm 5.2$ \\
5 & $87.0 \pm 3.3^{*}$ & 15 & $97.1 \pm 1.0$ \\
6 & $26.5 \pm 3.0^{* * *}$ & 16 & $83.9 \pm 2.2^{* * *}$ \\
7 & $74.9 \pm 4.4^{* * *}$ & &
\end{tabular}

Normal: normal group without LPS, DEX and other tested samples. Control: lipopolysaccharide (LPS). Positive control: Dexamethasone (Dex). Nitrite relative concentration (NRC): percentage of control groupn (set as $100 \%$ ). Values represent the mean \pm SD of three determinations. ${ }^{*} p<0.05 ; * * *<0.001$ (Differences between compound-treated group and control group). $n=4$. Final concentration was $40 \mu \mathrm{M}$ for $\mathbf{1 - 1 6}$, was $1.0 \mu \mathrm{g} / \mathrm{mL}$ for positive control (Dex), respectively.

The summary of anti-inflammatory activity of triterpenoids suggested that 3-C=O was the key group for the anti-inflammatory activity of triterpenoids (5 vs. 6; 9 vs. 10). Further, the different configuration of C-24 displayed a strong effect on their activities ( $24 S>24 R, 6$ vs. 7).

Moreover, a dose-dependent experiment was conducted for compounds 6, 7, 10 and 16 at the concentration of 10, 20, and $40 \mu \mathrm{M}$, respectively. Consequently, 6, 7, as well as 16 were found to inhibit NO release from RAW264.7 cells in a dose-dependent manner (Figure 5).
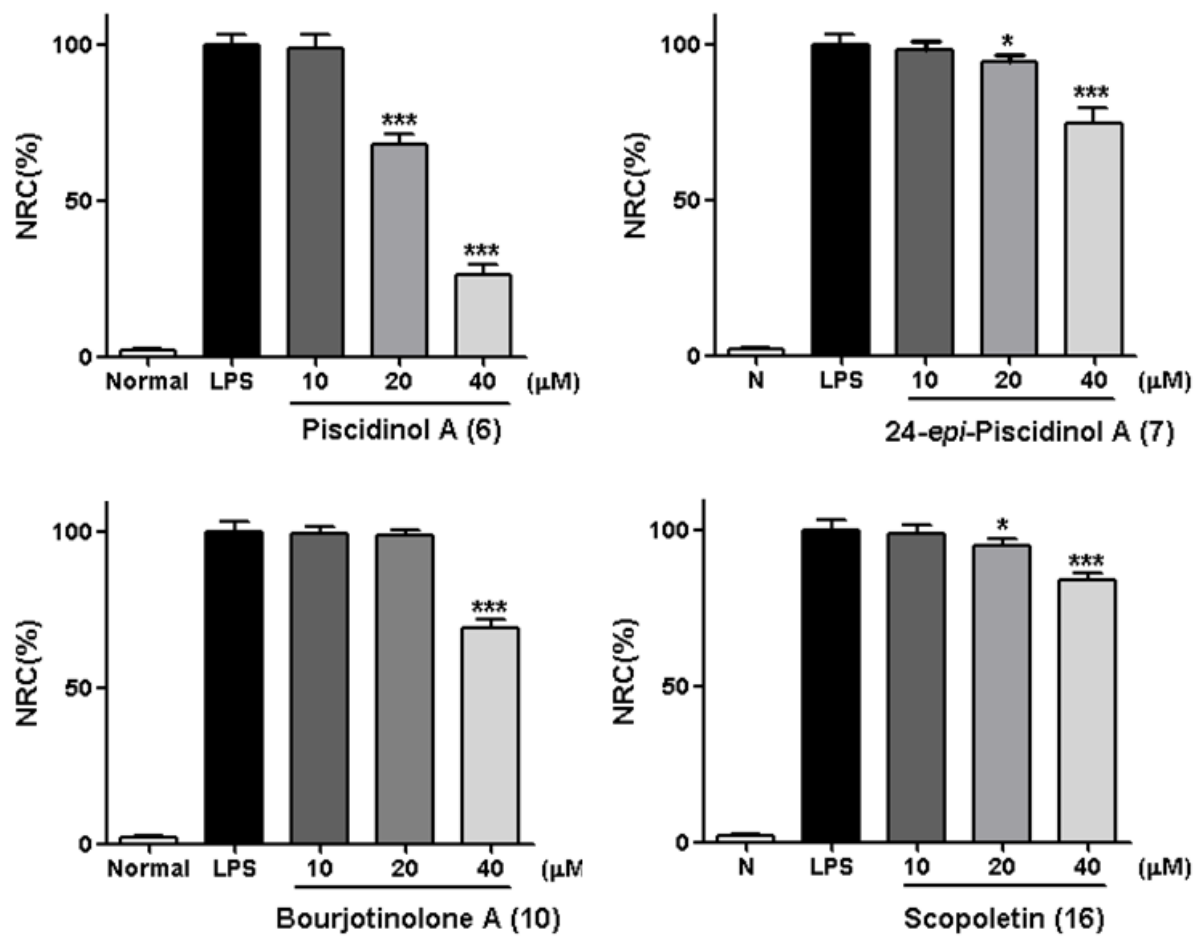

Figure 5. Inhibitory effects of compounds 6, 7, 10 and 16 at concentration of 10, 20, and $40 \mu \mathrm{M}$ on NO production in RAW 264.7 cells, respectively. Normal: the normal group without LPS and other tested samples. Nitrite relative concentration (NRC): percentage of control groupn (set as 100\%). Values represent the mean $\pm \mathrm{SD}$ of four determinations. ${ }^{*} p<0.05 ;{ }^{* * *} p<0.001$ (Differences between compound-treated group and control group). $n=4$. 
As we referred to in the Introduction, IL-6, NF-kB, and iNOS are the major inflammatory cytokines, the Western blot method was used to study the anti-inflamatory machanism of compounds 6, 7, 10, and 16 by determining their expressions in LPS-induced RAW264.7 cells. Comparing with the normal group, LPS led an obvious upregulation in the protein expressions of IL-6, NF- $\mathrm{B}$, and iNOS. Compounds 6, 7, 10, and 16 could inhibit the protein expressions of IL-6, NF- $\mathrm{B}$, and iNOS in the cells. And the activities of 6, 7, and 16 were found to exhibit in a dose-dependent manner (Figures 6-9).
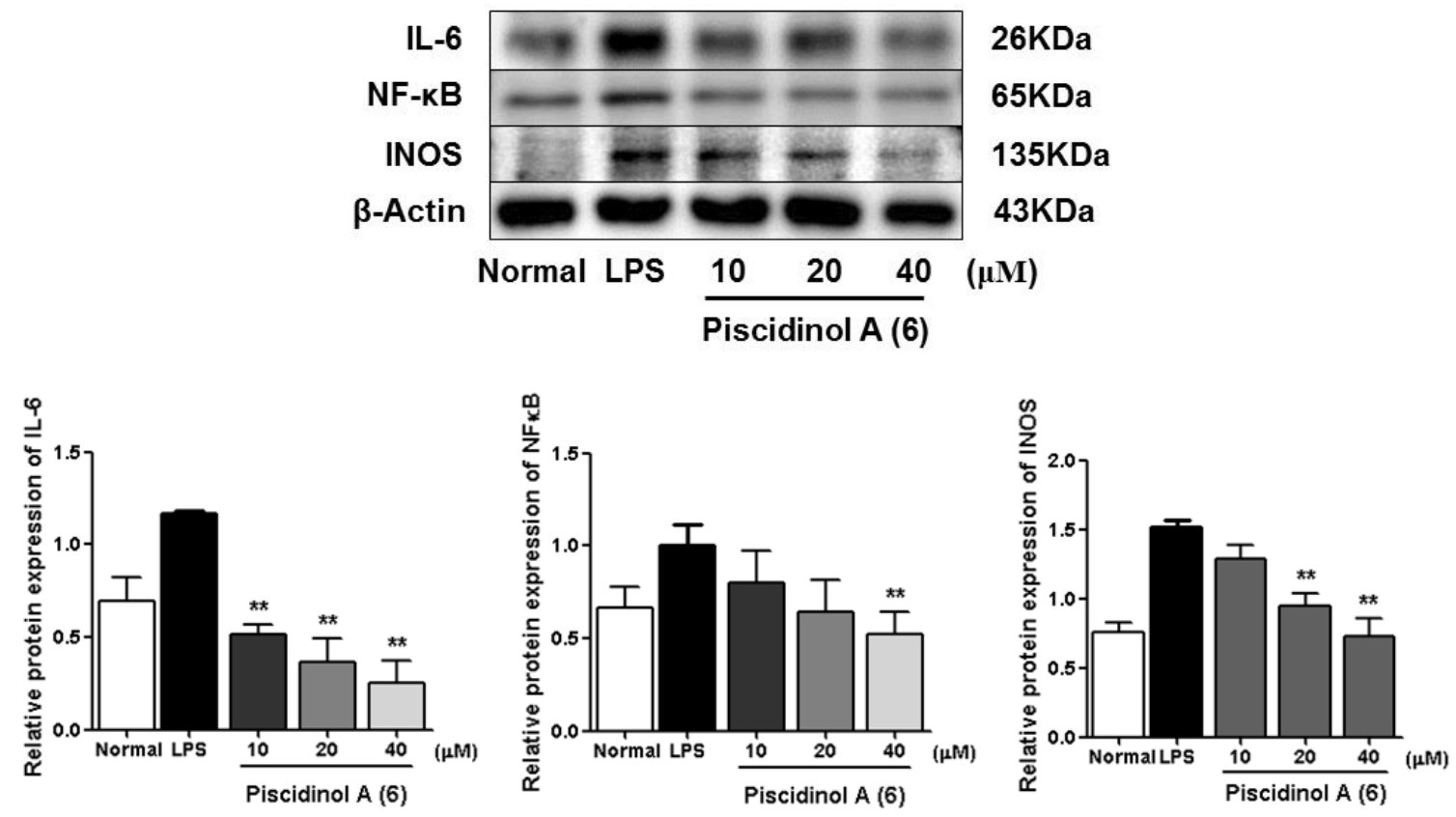

Figure 6. Inhibitory effects of compound 6 on the protein expression of IL-6, NF-kB and iNOS in RAW 264.7 cells. Normal: normal group without LPS, DEX and other tested samples. Values represent the mean \pm SEM of three determinations. ${ }^{* *} p<0.01$; (Differences between compound-treated group and control group). $n=3$.

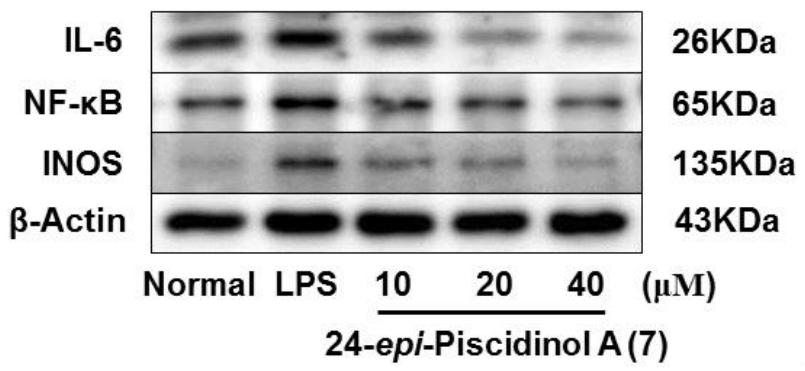

Figure 7. Cont. 

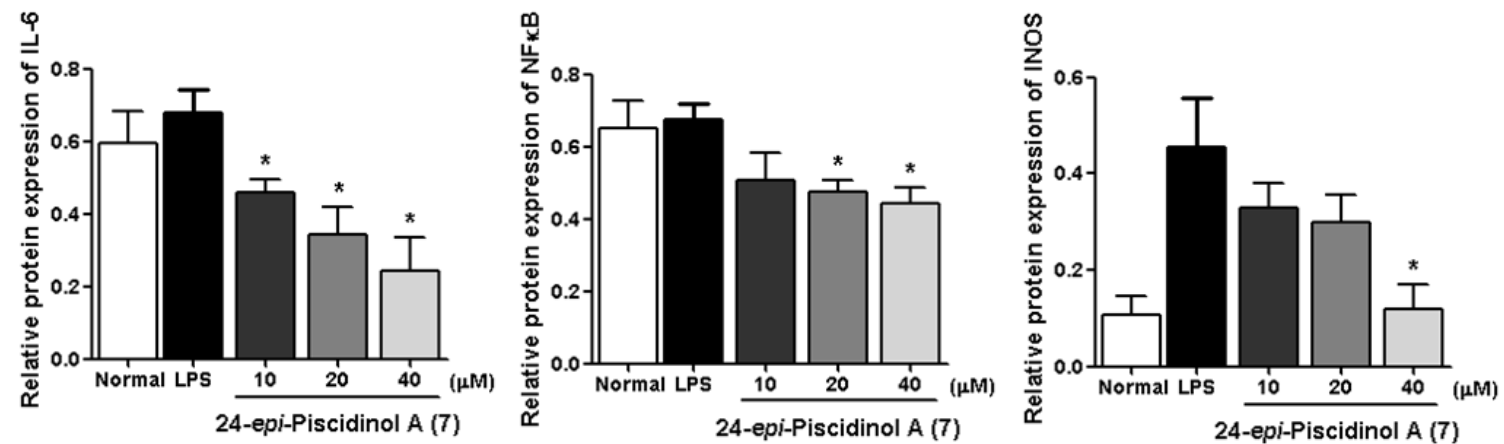

Figure 7. Inhibitory effects of compound 7 on the protein expression of IL-6, NF-kB and iNOS in RAW 264.7 cells. Normal: normal group without LPS, DEX and other tested samples. Values represent the mean \pm SEM of three determinations. ${ }^{*} p<0.05$ (Differences between compound-treated group and control group). $n=3$.
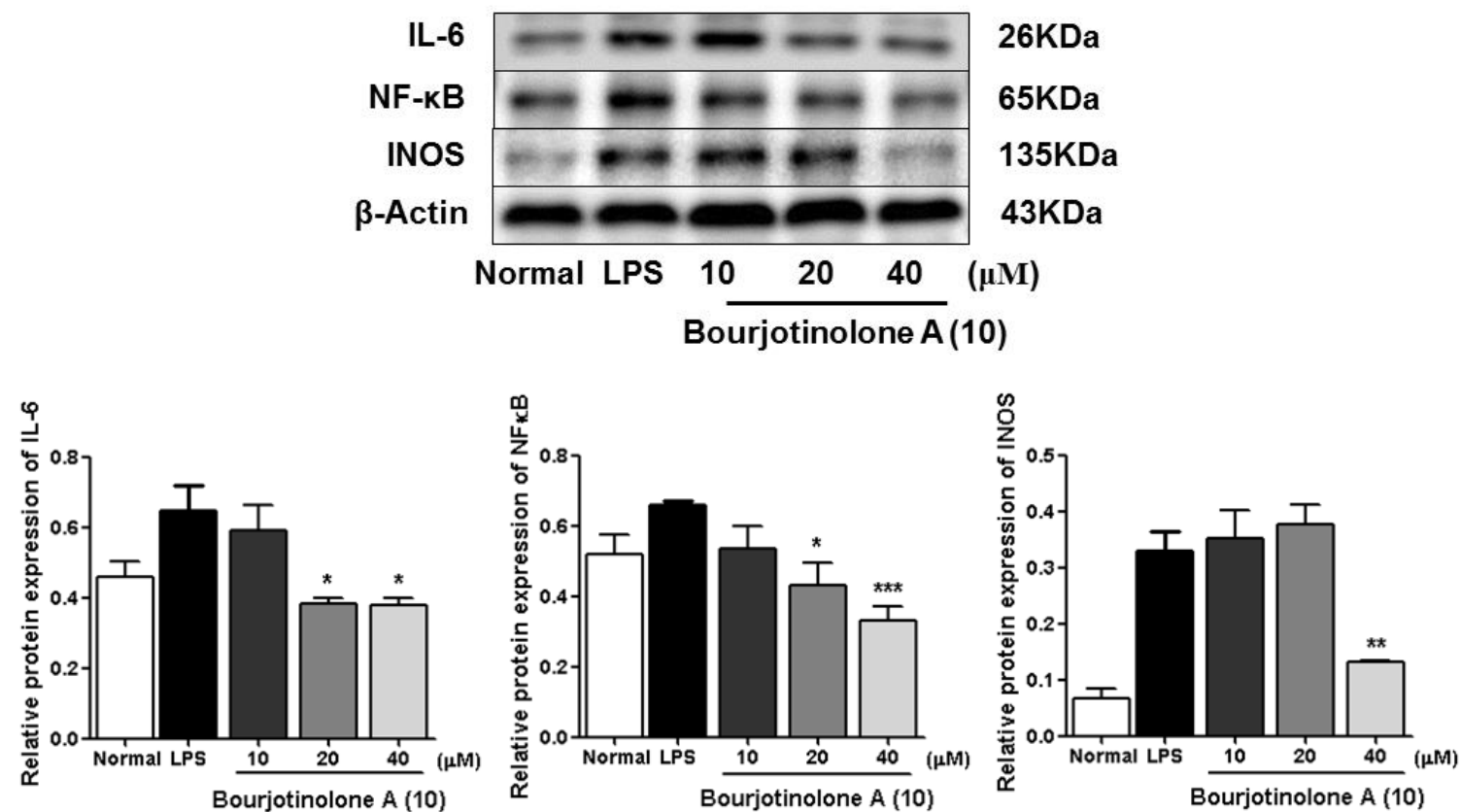

Figure 8. Inhibitory effects of compound $\mathbf{1 0}$ on the protein expression of IL-6, NF-KB and iNOS in RAW 264.7 cells. Normal: normal group without LPS, DEX and other tested samples. Values represent the mean \pm SEM of three determinations. ${ }^{*} p<0.05 ;{ }^{* *} p<0.01 ;{ }^{* *} p<0.001$ (Differences between compound-treated group and control group). $n=3$.

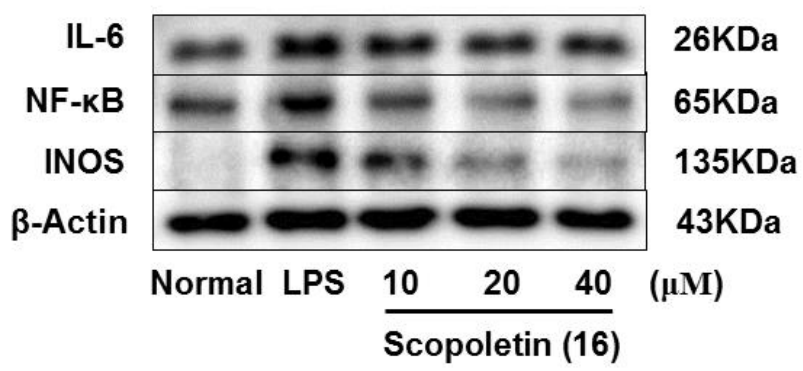

Figure 9. Cont. 

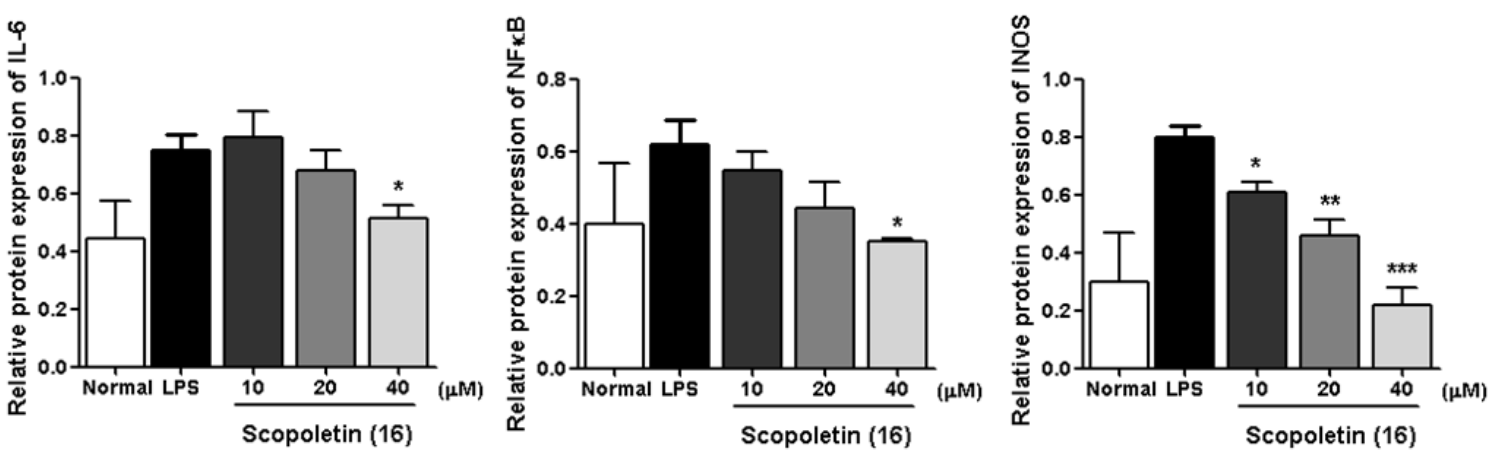

Figure 9. Inhibitory effects of compound $\mathbf{1 6}$ on the protein expression of IL-6, NF-kB and iNOS in RAW 264.7 cells. Normal: normal group without LPS, DEX and other tested samples. Values represent the mean \pm SEM of three determinations. ${ }^{*} p<0.05 ;{ }^{* *} p<0.01 ;{ }^{* *} p<0.001$ (Differences between compound-treated group and control group). $n=3$.

\section{Experimental}

\subsection{Experimental Procedures for Phytochmistry Study}

\subsubsection{General Experimental Procedures}

NMR spectra were determined on a Bruker ascend $600 \mathrm{MHz}$ and/or Bruker ascend $500 \mathrm{MHz}$ NMR spectrometer (Bruker BioSpin AG Industriestrasse 26 CH-8117, Fällanden, Switzerland) (internal standard: TMS). Positive- and Negative-ion mode HRESI-TOF-MS were measured on an Agilent Technologies 6520 Accurate-Mass Q-Tof LC/MS spectrometer (Agilent Corp., Santa Clara, CA, USA). Optical rotations, UV and IR spectra were run on a Rudolph Autopol ${ }^{\circledR}$ IV automatic polarimeter (1 = $50 \mathrm{~mm}$ ) (Rudolph Research Analytical, Hackettstown NJ, USA), Varian Cary 50 UV-Vis (Varian, Inc., Hubbardsdon, MA, USA) and Varian 640-IR FT-IR spectrophotometer (Varian Australia Pty Ltd., Mulgrave, Australia), respectively.

CC were performed over macroporous resin D101 (Haiguang Chemical Co., Ltd., Tianjin, China), silica gel (48-75 $\mu \mathrm{m}$, Qingdao Haiyang Chemical Co., Ltd., Qingdao, China), ODS (50 $\mu \mathrm{m}$, YMC Co., Ltd., Tokyo, Japan), and Sephadex LH-20 (Ge Healthcare Bio-Sciences, Uppsala, Sweden). High performance liquid chromatography (HPLC) column: Cosmosil 5C 18 -MS-II (4.6 mm i.d. $\times 250 \mathrm{~mm}, 5 \mu \mathrm{m})$ and Cosmosil 5C 18 -MS-II (20 mm i.d. $\times 250$ mm, $5 \mu \mathrm{m}$, Nakalai Tesque, Inc., Tokyo, Japan), Cosmosil PBr (4.6 mm i.d. $\times 250 \mathrm{~mm}, 5 \mu \mathrm{m})$ and Cosmosil PBr $(20 \mathrm{~mm}$ i.d. $\times 250 \mathrm{~mm}$, Nacalai Tesque, Inc., Kyoto, Japan), Cosmosil 5SL-II (4.6 mm i.d. $\times 250 \mathrm{~mm}, 5 \mu \mathrm{m})$ and 5SL-II $(20 \mathrm{~mm}$ i.d. $\times 250 \mathrm{~mm}, 5 \mu \mathrm{m}$, Nakalai Tesque, Inc., Tokyo, Japan), and Venusil PrepG C18 (50 mm i.d. × 250 mm, $10 \mu \mathrm{m}$, Agela technologies, Tianjin, China) were used to analysis and separate the constituents.

\subsubsection{Plant Material}

The roots of Eurycoma longifolia Jack were collected from the Nuang Mountain Recreation Forest in Selangor city, Malaysia, and identified by Dr. Wang Tao (Institute of Traditional Chinese Medicine, Tianjin University of Traditional Chinese Medicine). The voucher specimen was deposited at the Academy of Traditional Chinese Medicine of Tianjin University of TCM.

\subsubsection{Extraction and Isolation}

The dried roots of E. longifolia $(3.4 \mathrm{~kg}$ ) were cut to pieces and refluxed with $70 \% \mathrm{EtOH}$ to gain $70 \%$ EtOH extract $(160.0 \mathrm{~g}, \mathrm{EL})$. Then, EL (125.0 g) was partitioned in an EtOAc- $\mathrm{H}_{2} \mathrm{O}$ mixture $(1: 1, v / v)$ to obtain EtOAc layer (ELE, $35.5 \mathrm{~g}$ ) and $\mathrm{H}_{2} \mathrm{O}$ layer (85.0 g), respectively. The $\mathrm{H}_{2} \mathrm{O}$ layer was subjected to $\mathrm{D} 101$ macroporous resin $\mathrm{CC}\left(\mathrm{H}_{2} \mathrm{O} \rightarrow 95 \% \mathrm{EtOH}\right)$. As a result, $\mathrm{H}_{2} \mathrm{O}(50.8 \mathrm{~g})$ and 95\% $\mathrm{EtOH}(31.3 \mathrm{~g})$ eluates were obtained. 
The 95\% EtOH eluates $(25.0 \mathrm{~g})$ was subjected to ODS CC $\left[\mathrm{MeOH}-\mathrm{H}_{2} \mathrm{O}(10: 90 \rightarrow\right.$ 20:80 $\rightarrow$ 30:70 $\rightarrow$ $40: 60 \rightarrow 50: 50 \rightarrow 60: 40 \rightarrow$ 100:0, v/v)], and 19 fractions (ELG1-ELG19) were yielded. ELG2 (779.5 mg) was separated by pHPLC $\left[\mathrm{CH}_{3} \mathrm{CN}-1 \%\right.$ HAc $(10: 90, v / v)$, Cosmosil $\mathrm{PBr}$ column], and ten fractions (ELG2-1-ELG2-10) were given. ELG2-8 (42.3 mg) was isolated by pHPLC $\left[\mathrm{CH}_{3} \mathrm{CN}-1 \% \mathrm{HAc}\right.$ (10:90, $v / v)$, Cosmosil PBr column] to yield 3-chloro-4-hydroxyl benzoic acid-4-O- $\beta$-D-glucopyranoside (14, $15.7 \mathrm{mg})$. ELG3 (410.1 mg) was purified by pHPLC [ $\mathrm{CH}_{3} \mathrm{CN}-1 \% \mathrm{HAc}(8: 92, v / v)$, Cosmosil PBr column] to gain isotachioside (15, $13.9 \mathrm{mg})$. ELG9 (3.2 g) was subjected to pHPLC [ $\mathrm{CH}_{3} \mathrm{CN}-1 \%$ HAc (12:88, v/v), Venusil PrepG C18 column] to produce eight fractions (ELG9-1-ELG9-8). ELG9-4 (923.6 mg) was purified by pHPLC $\left[\mathrm{CH}_{3} \mathrm{CN}-1 \%\right.$ HAc $(9: 91, v / v)$, Cosmosil PBr column] to yield eurylophenoloside A (1, $7.9 \mathrm{mg})$. ELG15 (1490.0 mg) was subjected to Sephadex LH-20 CC [MeOH-H $\left.\mathrm{H}_{2} \mathrm{O}(1: 1, v / v)\right]$, and five fractions (ELG15-1-ELG15-5). ELG15-4 (283.3 mg) was isolated by pHPLC [ $\mathrm{CH}_{3} \mathrm{CN}-1 \% \mathrm{HAc}$ (17:83, v/v), Cosmosil PBr column] to yield eurylolignanoside A (3, 10.2 mg). ELG15-5 was purified by $\mathrm{pHPLC}\left[\mathrm{CH}_{3} \mathrm{CN}-1 \%\right.$ HAc $(19: 81, v / v)$, Cosmosil PBr column] to produce eurylolignanoside B (4, $16.3 \mathrm{mg})$. ELG16 $(841.3 \mathrm{mg})$ was separated by Sephadex LH-20 CC [MeOH-H $\left.\mathrm{H}_{2} \mathrm{O}(1: 1, v / v)\right]$ to give two fractions (ELG16-1-ELG16-2). ELG16-2 $\left(633.4 \mathrm{mg}\right.$ ) was isolated by pHPLC $\left[\mathrm{CH}_{3} \mathrm{CN}-1 \%\right.$ HAc $(22: 78, v / v)$, Cosmosil PBr column] to yield six fractions (ELG16-2-1-ELG16-2-6). ELG16-2-3 (33.7 mg) was further purified by pHPLC $\left[\mathrm{CH}_{3} \mathrm{CN}-1 \%\right.$ Hac $(22: 78, v / v)$, Cosmosil $5 \mathrm{C}_{18}$-MS-II column] to gain eurylophenoloside B (2, $5.0 \mathrm{mg})$.

ELE $(25.0 \mathrm{~g})$ was subjected to silica gel CC $\left[\mathrm{CH}_{2} \mathrm{Cl}_{2}\right.$-EtOAc $(50: 1 \rightarrow 20: 1 \rightarrow 5: 1 \rightarrow 2: 1 \rightarrow$ 1:1 $\rightarrow$ 1:20 $\rightarrow 1: 50 \rightarrow 0: 100, v / v) \rightarrow \mathrm{MeOH} \rightarrow \mathrm{MeOH}+\mathrm{NH}_{3} \cdot \mathrm{H}_{2} \mathrm{O}$ ] to produce thirteen fractions (ELE-1-ELE-13). ELE-6 $(2.0 \mathrm{~g})$ was separated by silica gel CC [PE-EtOAc $(100: 0 \rightarrow$ 98:2 $\rightarrow$ 94:6 $\rightarrow$ 90:10 $\rightarrow$ 88:12 $\rightarrow$ 84:16 $\rightarrow 76: 24 \rightarrow 72: 28 \rightarrow 0: 100, v / v)]$, and twelve fractions (ELE6-1-ELE6-12). ELE6-8 (102.6 mg) was purified by pHPLC [ $n$-hexane-EtOAc $(3: 1, v / v)$, Cosmosil 5SL-II column] to give bourjotinolone B $(8,11.3 \mathrm{mg})$. Using the same separation condition, bourjotinolone A $(\mathbf{1 0}, 60.3 \mathrm{mg})$ was obtained from ELE6-10 (179.6 mg). ELE-7 (2.2 g) was subjected to silica gel CC $\left[\mathrm{CH}_{2} \mathrm{Cl}_{2}\right.$-EtOAc $(100: 1 \rightarrow 100: 3 \rightarrow 100: 5 \rightarrow 100: 7$ $\rightarrow 10: 1 \rightarrow 5: 1 \rightarrow 10: 3 \rightarrow 2: 1 \rightarrow 1: 1 \rightarrow 0: 1, v / v) \rightarrow \mathrm{MeOH}$ ] to yield twenty-one fractions (ELE7-1-ELE7-21). ELE7-4 (62.1 mg) was isolated by pHPLC $\left[\mathrm{CH}_{2} \mathrm{Cl}_{2}\right.$-EtOAc (15:1, v/v), Cosmosil 5SL-II column] to give syringaldehyde $(\mathbf{1 2}, 3.9 \mathrm{mg})$ and scopoletin $(\mathbf{1 6}, 16.0 \mathrm{mg})$. ELE7-7 $(81.9 \mathrm{mg})$ was separated by pHPLC [ $\mathrm{CH}_{3} \mathrm{CN}-1 \% \mathrm{HAc}(23: 77, v / v)$, Cosmosil 5 $\mathrm{C}_{18}$-MS-II column] to yield 3-methoxy-4-hydroxybenzoic acid (11, $10.1 \mathrm{mg})$ and 3-chloro-4-hydroxybenzoic acid (13, $5.3 \mathrm{mg})$. ELE7-13 (131.8 $\mathrm{mg})$ was purified by pHPLC $\left[\mathrm{CH}_{2} \mathrm{Cl}_{2}-\mathrm{MeOH}(100: 2, v / v)\right.$, Cosmosil 5SL-II column] to give piscidinol A $(6,15.3 \mathrm{mg})$ and 3-episapeline A $(\mathbf{9}, 6.0 \mathrm{mg})$. ELE7-14 $(76.2 \mathrm{mg})$ was isolated by pHPLC $\left[\mathrm{CH}_{2} \mathrm{Cl}_{2}-\mathrm{MeOH}(100: 2, v / v)\right.$, Cosmosil 5SL-II column] to gain hispidol B $(5,2.6 \mathrm{mg})$ and 24-epi-piscidinol A $(7,2.7 \mathrm{mg})$.

Eurylophenoloside $A$ (1): White powder; $[\alpha]_{\mathrm{D}}^{25}-79.0$ (c 0.20, MeOH); $\mathrm{UV} \lambda_{\max }(\mathrm{MeOH}) \mathrm{nm}(\log \varepsilon)$ 250 (3.91), 256 (3.94), 263 (3.81); IR (KBr) $v_{\max } 3374$, 2935, 2884, 1601, 1505, 1462, 1421, 1228, 1197, 1126, $1067 \mathrm{~cm}^{-1} ;{ }^{1} \mathrm{H}$ NMR $\left(\mathrm{C}_{5} \mathrm{D}_{5} \mathrm{~N}, 600 \mathrm{MHz}\right)$ and ${ }^{13} \mathrm{C}$ NMR $\left(\mathrm{C}_{5} \mathrm{D}_{5} \mathrm{~N}, 150 \mathrm{MHz}\right)$ see Table 1 . HRESI-TOF-MS $m / z 633.2005[\mathrm{M}+\mathrm{Na}]^{+}$(calcd for $\mathrm{C}_{25} \mathrm{H}_{38} \mathrm{O}_{17} \mathrm{Na}$, 633.2001).

Eurylophenoloside $B$ (2): White powder; $[\alpha]_{\mathrm{D}}{ }^{25}-34.7$ ( c 0.15, MeOH); UV $\lambda_{\max }(\mathrm{MeOH}) \mathrm{nm}(\log \varepsilon)$ : 222 (4.29, sh), 278 (3.85); IR (KBr) $v_{\max } 3357,2932,2886,2837,1704,1603,1506,1462,1423,1379,1335$, $1275,1225,1129,1076,1041 \mathrm{~cm}^{-1} ;{ }^{1} \mathrm{H}$ NMR $\left(\mathrm{C}_{5} \mathrm{D}_{5} \mathrm{~N}, 500 \mathrm{MHz}\right)$ and ${ }^{13} \mathrm{C}$ NMR $\left(\mathrm{C}_{5} \mathrm{D}_{5} \mathrm{~N}, 125 \mathrm{MHz}\right)$ see Table 2. HRESI-TOF-MS $m / z$ 813.2438 [M $+\mathrm{H}]^{+}$(calcd for $\mathrm{C}_{34} \mathrm{H}_{47} \mathrm{O}_{21}, 813.2424$ ).

Eurylolignanoside $A$ (3): White powder; $[\alpha]_{\mathrm{D}}^{25}-47.2$ (c 0.25, MeOH); UV $\lambda_{\max }(\mathrm{MeOH}) \mathrm{nm}(\log$ ع): 217 (4.26, sh), 267 (3.86); CD (conc $0.007 \mathrm{M}, \mathrm{MeOH}) \mathrm{mdeg}(\lambda \mathrm{nm}):-62.6(225 \mathrm{~nm}),-23.1(259 \mathrm{~nm})$; IR $v_{\max }(\mathrm{KBr}): 3382,2923,2881,1712,1586,1515,1461,1423,1376,1314,1273,1228,1154,1073$, $1040 \mathrm{~cm}^{-1} ;{ }^{1} \mathrm{H}$ NMR $\left(\mathrm{CD}_{3} \mathrm{OD}, 500 \mathrm{MHz}\right)$ and ${ }^{13} \mathrm{C} \mathrm{NMR}\left(\mathrm{CD}_{3} \mathrm{OD}, 125 \mathrm{MHz}\right)$ see Table 3. HRESI-TOF-MS $\mathrm{m} / \mathrm{z}$ 707.2521 [M + Na] $]^{+}$(calcd for $\mathrm{C}_{32} \mathrm{H}_{44} \mathrm{O}_{16} \mathrm{Na}, 707.2522$ ).

Eurylolignanoside $B$ (4): White powder; $[\alpha]_{\mathrm{D}}^{25}-42.5(c 0.40, \mathrm{MeOH}) ; \mathrm{UV} \lambda_{\max }(\mathrm{MeOH}) \mathrm{nm}(\log \varepsilon)$ 232 (3.71, sh), 284 (3.41); CD (conc 0.008 M, MeOH) mdeg ( $\lambda \mathrm{nm}):-15.1(231 \mathrm{~nm}),-4.2(291 \mathrm{~nm}) ; \mathrm{IR}(\mathrm{KBr})$ $v_{\max } 3408,2935,2851,1702,1600,1557,1516,1460,1423,1390,1273,1211,1152,1070,1031 \mathrm{~cm}^{-1} ;{ }^{1} \mathrm{H}$ 
NMR $\left(\mathrm{CD}_{3} \mathrm{OD}, 500 \mathrm{MHz}\right)$ and ${ }^{13} \mathrm{C}$ NMR $\left(\mathrm{CD}_{3} \mathrm{OD}, 125 \mathrm{MHz}\right)$ see Table 4. HRESI-TOF-MS $\mathrm{m} / \mathrm{z} 509.1664$ $[\mathrm{M}-\mathrm{H}]^{-}$(calcd for $\left.\mathrm{C}_{24} \mathrm{H}_{29} \mathrm{O}_{12}, 509.1666\right)$.

3-Chloro-4-hydroxyl benzoic acid-4-O- $\beta$-D-glucopyranoside (14): White powder; ${ }^{1} \mathrm{H} N M R\left(\mathrm{C}_{5} \mathrm{D}_{5} \mathrm{~N}\right.$, $500 \mathrm{MHz}): \delta 8.47(1 \mathrm{H}, \mathrm{d}, J=1.5 \mathrm{~Hz}, \mathrm{H}-2), 7.67(1 \mathrm{H}, \mathrm{d}, J=8.5 \mathrm{~Hz}, \mathrm{H}-5), 8.21(1 \mathrm{H}, \mathrm{dd}, J=1.5,8.5 \mathrm{~Hz}, \mathrm{H}-6)$, $5.80\left(1 \mathrm{H}, \mathrm{d}, J=7.5 \mathrm{~Hz}, \mathrm{H}-1^{\prime}\right), 4.38\left(1 \mathrm{H}, \mathrm{m}\right.$, overlapped, $\left.\mathrm{H}-2^{\prime}\right), 4.37\left(1 \mathrm{H}, \mathrm{m}\right.$, overlapped, $\left.\mathrm{H}-3^{\prime}\right), 4.32(1 \mathrm{H}$, $\left.\mathrm{dd}, J=8.5,8.5 \mathrm{~Hz}, \mathrm{H}-4^{\prime}\right), 4.15\left(1 \mathrm{H}, \mathrm{m}, \mathrm{H}-5^{\prime}\right),[4.38(1 \mathrm{H}, \mathrm{m}$, overlapped $), 4.53(1 \mathrm{H}, \mathrm{dd}, J=2.5,12.0 \mathrm{~Hz})$, $\left.\mathrm{H}_{2}-6^{\prime}\right] ;{ }^{13} \mathrm{C}$ NMR $\left(\mathrm{C}_{5} \mathrm{D}_{5} \mathrm{~N}, 125 \mathrm{MHz}\right): \delta 127.1$ (C-1), 132.2 (C-2), 123.0 (C-3), 157.1 (C-4), 115.9 (C-5), 130.4 (C-6), 167.8 (C-7), 101.8 (C-1'), $74.7\left(\mathrm{C}-2^{\prime}\right), 78.6$ (C-3'), 71.0 (C-4'), 79.2 (C-5'), 62.3 (C-6') data were firstly reported here; HRESI-TOF-MS $m / z 333.0383$ [M - H] ${ }^{-}$(calcd for $\mathrm{C}_{13} \mathrm{H}_{14} \mathrm{ClO}_{8}, 333.0389$ ).

Acid hydrolysis of 1-4: The acid hydrolysis reactions of 1-4 were conducted by using the method reported previously [24]. As a result, D-glucose (12.4 min, positive optical rotation) for 1-4 was identified by a comparison of their retention time and optical rotation with that of an authentic sample.

\subsection{Experimental Procedures for Bioassay}

\subsubsection{General Experimental Procedures}

MTT and nitrite levels were measured on a BioTek Cytation five-cell imaging multi-mode reader (Winooski, VT, USA); protein bands were mixed with Enhanced Chemiluminescence (Millipore, Billerica, MA, USA); protein bands were visualized with the Amersham imager 600 luminescent image analyzer (GE healthcare Japan Co., Tokyo, Japan).

RAW264.7 cells were obtained from the cell center at the Chinese Academy of Medical Science; LPS and Dex were purchased from Sigma Chemical (St. Louise, MO, USA); penicillin and streptomycin were purchased from Thermo Fisher Scientific (Waltham, MA); dulbecco's modified eagle medium (DMEM) and fetal bovine serum (FBS) were purchased from Biological Industries (Beit Haemek, IN); nitric oxide fluorometric assay kit was purchased from Beyotime Biotechnology (Shanghai, China); bicinchoninic acid protein assay kit was purchased from Thermo Fisher Scientific (Waltham, MA, USA). Rabbit anti-IL-6 was purchased from Proteintech Group, Inc (Chicago, IL, USA). Rabbit anti-NF- $k B$, iNOS, and $\beta$-actin were purchased from Abcam plc. (Cambridge, MA, USA). Horseradish peroxidase-conjugated anti-rabbit immunoglobulin $\mathrm{G}(\mathrm{IgG})$ was purchased from Zhongshan Goldbridge Biotechnology (Beijing, China).

\subsubsection{Cell Culture}

RAW 264.7 cells were maintained in high glucose DMEM supplemented with $10 \%$ heat-inactivated FBS, $100 \mathrm{U} / \mathrm{mL}$ penicillin, and $100 \mu \mathrm{g} / \mathrm{mL}$ streptomycin in a humidified atmosphere containing $5 \% \mathrm{CO}_{2}$ at $37^{\circ} \mathrm{C}$. Cells were grown to $80 \%$ confluence and then seeded at $2 \times 10^{6}$ cells $/ \mathrm{mL}$ density in 24 -well plates incubated before treatment.

\subsubsection{Cell Viability Assay}

MTT colorimetric assay was used to determine cell viability. In brief, RAW 264.7 cells were seeded in 24-well plastic plates and treated without or with test samples $(40 \mu \mathrm{M})$ for $24 \mathrm{~h}$, respectively. The culture condition was the same as 3.2.2. The medium was removed, and the cells were incubated with $0.5 \mathrm{mg} / \mathrm{mL}$ of MTT solution. After $4 \mathrm{~h}$ incubation, the supernatant was removed and formation of formazan. The absorbance at $490 \mathrm{~nm}$ was measured with a microplate reader.

\subsubsection{Measurement of NO levels}

Initially, $2 \times 10^{6}$ cells/mL RAW264.7 cells were seeded on a 24-well plate and incubated overnight. After $24 \mathrm{~h}$, the media were changed, which contained LPS $(0.5 \mu \mathrm{g} / \mathrm{mL})$ with or without tested compounds 1-16 $(40 \mu \mathrm{M})$, as well as the positive drug DEX $(1 \mu \mathrm{g} / \mathrm{mL})$, and then, the cells were incubated for $24 \mathrm{~h}$. The cell supernatant was collected to detect NO levels, and cells were harvested for protein analysis. 


\subsubsection{Western Blot Analysis}

As described previously [28], the RAW264.7 cells treated with LPS were analyzed by Western blot. The protein concentrations in the supernatants and tissues were quantified using a bicinchoninic acid protein assay kit. Firstly, $60 \mu \mathrm{g}$ of protein was mixed with $4 \times$ loading dye (Laemmli Buffer) and 2-mercapto ethanol, before being heated at $100{ }^{\circ} \mathrm{C}$ for $5 \mathrm{~min}$. The protein was resolved by $10 \%$ sodium dodecyl sulfate polyacrylamide gel electrophoresis and transferred to immunoblot polyvinylidene difluoride (PVDF) membranes (Merck Millipore Ltd., Darmstadt, Germany). The membranes were incubated at $4{ }^{\circ} \mathrm{C}$ overnight with primary antibodies against IL-6 (1:1000) (21865-1-AP, Proteintech), NF-kB (1:500) (ab16502, Abcam), iNOS (1:1000) (ab3523, Abcam), and $\beta$-actin (1:1000) (ab8227, Abcam). Then, the membranes were washed three times with Tris-buffered saline/Tween 20 (TBS-T; $10 \mathrm{~min}$ each time) and incubated with a horseradish peroxidase-labeled secondary goat anti-rabbit $(1: 10,000)$ antibody for $1 \mathrm{~h}$ at room temperature. Next, the blots were again washed three times with TBS-T (10 min each time).

Finally, protein bands were mixed with enhanced chemiluminescence (Millipore Co., Ltd., MA, USA). Subsequently, the protein bands were visualized with the Amersham imager 600 luminescent image analyzer. The intensities of protein bands were quantified by Image J analysis software.

\subsubsection{Statistical Analysis}

Values are expressed as mean \pm S.D. SPSS 17.0 was used to conduct the statistics of all the grouped data. $p<0.05$ was considered to indicate statistical significance. One-way analysis of variance (ANOVA) and Tukey's studentized range test were used for the evaluation of the significant differences between means and post hoc, respectively.

\section{Conclusions}

In summary, four new phenolic acids, eurylophenolosides A (1) and B (2), eurylolignanosides A (3) and B (4), along with twelve known isolates were obtained from the $70 \%$ ethanol extract of E. longifolia roots by a combination of various chromatographic methods and spectral techniques. Among the known compounds, 12-15 were isolated from the Eurycoma genus for the first time. Furthermore, the NMR data of $\mathbf{1 4}$ was firstly reported here.

Compounds 6, 7, 10, and 16 showed significant inhibitory activity on NO release from RAW264.7 cells. In order to make the mechanism of their anti-inflammatory activities clear, Western blot assays were conducted. As a result, all of them were found to inhibit the LPS-induced protein expression of IL-6, NF- $\mathrm{kB}$, and iNOS in the NF- $\mathrm{kB}$ signaling pathway. Moreover, the protein expression inhibitory effects of 6,7 , and 16 were found to be in a dose-dependent manner. The mechanism may be related to inhibiting the IL-6-induced NF- $\mathrm{kB}$ pathway to suppress iNOS expressions. The experiment suggested terpenes and coumarins might also be the anti-inflammatory substances in E. longifolia roots, except for alkaloids [13].

On the other hand, acording to references, compound $\mathbf{1 6}$ possessed the ability to down-regulate the protein expression level of IL-6 and NF-kB [29], as well as the gene expression level of iNOS [30], which was identical to our experimental results. Meanwhile, although compounds 6, 7, and 10 have been reported to possess in vitro anti-inflammatory activities [31,32], their anti-inflammatory mechanisms have not yet been reported. Thus, our investigation not only verified the research on the anti-inflammatory mechanism of compound 16, but also complemented the blank of exisiting literature on the anti-inflammation mechanisms of compounds 6, 7, and 10. Furtherly, the strong inhibitory activities of compound 6 indicated that it could be the drug candidates for inflammation-related diseases.

Supplementary Materials: The following are available online: Supplementary data (The NMR and HRESIMS spectra of compounds 1-4, cell viability assay, as well as the raw data for western blot assays) associated with this article can be found in the online version. 
Author Contributions: Y.Z. (Yi Zhang) and T.W. designed the research and wrote the manuscript; Z.L., and J.R. performed the experimental work; Y.Z. (Ying Zhang) and Y.C. corrected the data and reviewed literatures, M.L. and L.H. perfected the language. All authors discussed, edited, and approved the final version.

Funding: This work was financially supported by grants from National Natural Science Foundation of China (81673688) and Important Drug Development Fund, Ministry of Science and Technology of China (2018ZX09711001-009-010, 2018ZX09735002).

Acknowledgments: We are grateful to Yi Zhong of Global Education Network Sdn. Bhd. in Malaysia for providing the roots of E. longifolia.

Conflicts of Interest: The authors declare no conflict of interest.

\section{References}

1. Ahujaa, A.; Kim, M.Y.; Cho, J.Y. Protium javanicum Burm. methanol extract attenuates LPS-induced inflammatory activities in macrophage-like RAW264.7 cells. Evid. Based Complement Alternat. Med. 2019, 2019, 2910278. [CrossRef] [PubMed]

2. Mosser, D.M.; Edwards, J.P. Exploring the full spectrum of macrophage activation. Nat. Rev. Immunol. 2008, 8, 958-969. [CrossRef] [PubMed]

3. Fang, Y.; Mao, X. Culture skill and experience of RAW264.7*. Xiandai Shengwu Yixue Jinzhan 2012, 12, 4358-4359.

4. Liu, H.; Yao, Y. Advances in cross-talk of cellular signalling pathways associated with inflammatory response. Zhongguo Bingli Shengli Zazhi 2005, 21, 1607-1613, 1627.

5. Ling, M.; He, C.; Gao, J.; Wang, H. Research progresses on Eurycoma longifolia. Guangdong Linye Keji 2013, 29, 66-73.

6. Bhat, R.; Karim, A.A. Tongkat Ali (Eurycoma longifolia Jack): A review on its ethnobotany and pharmacological importance. Fitoterapia 2010, 81, 669-679. [CrossRef] [PubMed]

7. Hou, W.; Xiao, X.; Guo, W.; Zhang, T. Advances in studies on chemistry, pharmacological effect, and harmacokinetics of Eurycoma longifolia. Chin. Herb. Med. 2011, 3, 186-195.

8. Muhammad, I.; Samoylenko, V. Antimalarial quassinoids: Past, present and future. Expert. Opin. Drug Discov. 2007, 2, 1065-1084. [CrossRef] [PubMed]

9. Park, S.; Nhiem, N.X.; Kiem, P.V.; Minh, C.V.; Tai, B.H.; Kim, N.; Yoo, H.H.; Song, J.H.; Ko, H.J.; Kim, S.H. Five new quassinoids and cytotoxic constituents from the roots of Eurycoma longifolia. Bioorg. Med. Chem. Lett. 2014, 24, 3835-3840. [CrossRef] [PubMed]

10. Kuo, P.C.; Shi, L.S.; Damu, A.G.; Su, C.R.; Huang, C.H.; Ke, C.H.; Wu, J.B.; Lin, A.J.; Bastow, K.F.; Lee, K.H.; et al. Cytotoxic and antimalarial $\beta$-carboline alkaloids from the roots of Eurycoma longifolia. J. Nat. Prod. 2003, 66, 1324-1327. [CrossRef]

11. Chan, K.L.; O’Neill, M.J.; Phillipson, J.D.; Warhurst, D.C. Plants as sources of antimalarial drugs. Part 3. Eurycoma longifolia. Planta Med. 1986, 50, 105-107. [CrossRef]

12. Ngoc, P.B.; Pham, T.B.; Nguyen, D.; Tran, T.T.; Chu, H.H.; Chau, V.M.; Lee, J.H.; Nguyen, T.D. A new anti-inflammatory $\beta$-carboline alkaloid from the hairy-root cultures of Eurycoma longifolia. Nat. Prod. Res. 2016, 30, 1360-1365. [CrossRef] [PubMed]

13. Han, Y.M.; Woo, S.U.; Choi, M.S.; Park, Y.N.; Kim, S.H.; Yim, H.; Yoo, H.H. Antiinflammatory and analgesic effects of Eurycoma longifolia extracts. Arch. Pharm. Res. 2016, 39, 421-428. [CrossRef] [PubMed]

14. Liu, J.; Zhang, Z.; Yao, J.; Wang, J.; Zhao, M.; Zhang, S. Chemical constituents of the branches of Ailanthus altissima Swingle. Linchan Huaxue Yu Gongye 2013, 33, 121-127.

15. Zhang, F.; Cen, J.; Li, Q.; Wang, H. Chemical constituents from Toona ciliata var. henryi and their anti-inflammatory activities. Zhongcaoyao 2014, 45, 755-759.

16. Puripattanavong, J.; Weber, S.; Brecht, V.; Frahm, A.W. Phytochemical investigation of Aglaia andamanica. Planta Med. 2000, 66, 740-745. [CrossRef] [PubMed]

17. Wang, X.N.; Fan, C.Q.; Yin, S.; Lin, L.P.; Ding, J.; Yue, J.M. Cytotoxic terpenoids from Turraea pubescens. Helv. Chim. Acta 2008, 91, 510-518. [CrossRef]

18. Zheng, R.; Ya, J.; Wang, W.; Yang, H.; Zhang, Q.; Zhang, X.; Ye, W. Chemical studies on roots of Ficus hirta. Zhongguo Yaowu Huaxue Zazhi 2013, 38, 3696-3701. 
19. Xu, W.; Zhou, G.; Dai, Y.; Yao, X. Chemical constituents in stems of Schima superba. Zhongcaoyao 2010, 41, 863-866.

20. Kuo, P.C.; Damu, A.G.; Lee, K.H.; Wu, T.S. Cytotoxic and antimalarial constituents from the roots of Eurycoma longifolia. Bioorg. Med. Chem. 2004, 12, 537-544. [CrossRef] [PubMed]

21. Mei, W.; Dai, H.; Wu, D. Phenolic constituents from Ailanthus fordii Nooteboom. Redai Yaredai Zhiwu Xuebao 2006, 14, 413-416.

22. Zhang, D.; Li, Y.; Yu, S. Glycosides from the stems of Photinia parvifolia. Tianran Chanwu Yanjiu Yu Kaifa 2004, 16, 496-499.

23. Jiang, C.; Mu, S.; Deng, B.; Ge, Y.; Zhang, J.; Hao, X. Isolation and identification of chemical constituents from aerial part of Euphorbia chrysocoma Lévi. et Vant (II). Shenyang Yaoke Daxue Xuebao 2010, 27, 354-356.

24. Qu, L.; Wang, J.; Ruan, J.; Yao, X.; Huang, P.; Wang, Y.; Yu, H.; Han, L.; Zhang, Y.; Wang, T. Spirostane-type saponins obtained from Yucca schidigera. Molecules 2018, 23, 167. [CrossRef] [PubMed]

25. Ishii, T.; Yanagisawa, M. Systhesis, separation and NMR spectral analysis of methyl apiofuranosides. Carbohyd. Res. 1998, 313, 189-192. [CrossRef]

26. Zhang, Y.; Chao, L.; Ruan, J.; Zheng, C.; Yu, H.; Han, L.; Wang, T. Bioactive constituents from the rhizomes of Dioscorea septemloba Thunb. Fitoterapia 2016, 115, 165-172. [CrossRef] [PubMed]

27. Zhuo, J.X.; Wang, Y.H.; Su, X.L.; Mei, R.Q.; Yang, J.; Kong, Y.; Long, C.L. Neolignans from Selaginella moellendorffii. Nat. Prod. Bioprospect. 2016, 6, 161-166. [CrossRef]

28. He, W.; Li, Y.; Liu, M.; Yu, H.; Chen, Q.; Chen, Y.; Ruan, J.; Ding, Z.; Zhang, Y.; Wang, T. Citrus aurantium L. and its flavonoids regulate TNBS-induced inflammatory bowel disease through anti-inflammation and suppressing isolated jejunum contraction. Inter. Int. J. Mol. Sci. 2018, 19, 3057. [CrossRef]

29. Ibrahim, S.R.M.; Abdallah, H.M.; El-Halawany, A.M.; Esmat, A.; Mohamed, G.A. Thiotagetin B and tagetannins $\mathrm{A}$ and $\mathrm{B}$, new acetylenic thiophene and digalloyl glucose derivatives from Tagetes minuta and evaluation of their in vitro antioxidative and anti-inflammatory activity. Fitoterapia 2018, 125, 78-88. [CrossRef]

30. Sundaram, C.S.; Rao, U.S.M.; Simbak, N. Regulatory efficacy of scopoletin, a biocoumarin on aortic oxido lipidemic stress through antioxidant potency as well as suppression of mRNA expression of inos gene in hypercholesterolemic rats. Pharm. Lett. 2015, 7, 57-67.

31. Chen, H.; Ma, S.G.; Fang, Z.F.; Bai, J.; Yu, S.S.; Chen, X.G.; Hou, Q.; Yuan, S.P.; Chen, X. Tirucallane triterpenoids from the stems of Brucea mollis. Chem. Biodiver. 2013, 10, 695-702. [CrossRef] [PubMed]

32. Raju, R.; Singh, A.; Reddell, P.; Munch, G. Anti-inflammatory activity of prenyl and geranyloxy furanocoumarins from Citrus garrawayi (Rutaceae). Phytochem. Lett. 2018, 27, 197-202. [CrossRef]

Sample Availability: Samples of the compounds 1-16 are available from the authors.

(C) 2019 by the authors. Licensee MDPI, Basel, Switzerland. This article is an open access article distributed under the terms and conditions of the Creative Commons Attribution (CC BY) license (http://creativecommons.org/licenses/by/4.0/). 